\title{
Skills frameworks: A focus on supply chains
}

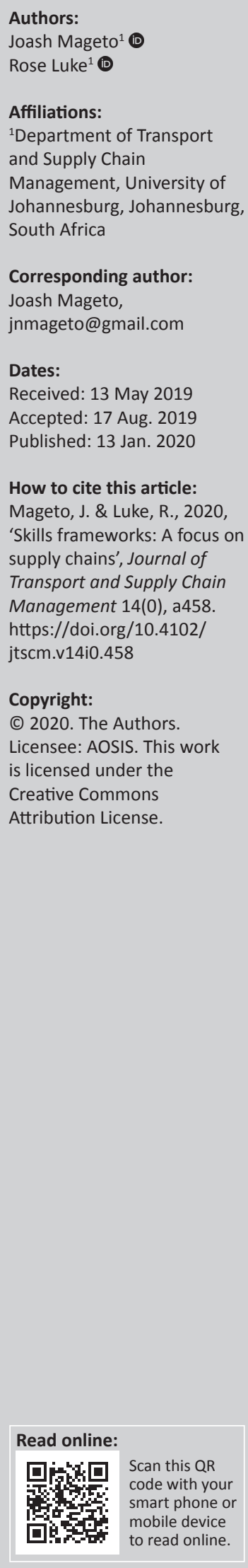

Background: Supply chain management (SCM) has grown considerably, owing largely to globalisation, advancements in technology and its pivotal role in meeting the dynamic needs of customers. As supply chains (SCs) expand, complexity also increases, as does the associated demand for well-skilled SC professionals. To achieve the expected SCM skills in organisations, a skills framework is likely to guide managers and practitioners. Unfortunately, research on SCM skills frameworks is fragmented, providing little or no guidance to practitioners.

Objectives: The purpose of this study was to document the SC skills described in the literature, identify existing frameworks and propose a framework to guide practitioners and academics.

Method: A systematic literature review design was followed. The data obtained were analysed using content analysis.

Results: About 270 SCM skills were identified. The skills were grouped using many SC skills frameworks, including business logistics management, T-shaped, expertise level, SCM skills and hard and soft skills. The proposed skills framework included skills related to business, logistics, management, and ethics and environment. Emerging skills such as the application of blockchain technology, big data and SC sustainability have been included in the framework.

Conclusion: The proposed framework provides a guide to SC managers about which skills groups to focus on and advises a contingency-based approach to identify the relevant skills per group in line with organisational requirements.

Keywords: supply chain management skills; systematic review; skills frameworks; content analysis; Atlas.ti 8.

\section{Introduction}

Business enterprises have witnessed considerable growth in the value and importance of logistics and supply chain management (SCM) since the 1990s (Murphy \& Poist 2007). Supply chain management growth can largely be attributed to globalisation, use of advanced technologies, increased e-commerce and the dynamic nature of customer expectations (Kotzab et al. 2018). The continued growth of SCM across the world has resulted in enterprises managing large and sometimes complex global supply chain (SC) operations. As SCs expand to new areas within a country or across the world, complexity increases because of turbulent and competitive business environments, the need to balance cost efficiencies and customer service levels, as well as managing relationships with suppliers and customers (Thai 2012). This complexity demands that employees managing SC operations should be highly skilled. Past research (Murphy \& Poist 1991; Thai 2012) has determined a variety of SCM skills required to adequately perform SC functions. There is a long list of SC skills in the literature, which include core logistics and SC, general management and information technology (IT)-related skills (Mangan \& Christopher 2005; Murphy \& Poist 1991; Wu 2006). However, there is little consensus among researchers regarding SCM skills and their groupings hitherto (Tatham et al. 2017). For instance, some researchers have categorised the skills into three areas (Murphy \& Poist 1991), four (Rahman \& Qing 2014), five (Sinha, Millhiser \& He 2016) and six (Heyns \& Luke 2012) areas. As such, the existing literature on the SC skills framework is highly fragmented in terms of defining skills frameworks, for example, business logistics management (BLM) by Murphy and Poist (1991), T-shaped skills grouping by Mangan and Christopher (2005) and Heyns and Luke's (2012) framework. The number of skills and actual skills included in each framework also varies from one framework to another. Although subsequent frameworks have included emerging skills in SCM (Tatham et al. 2017; Thai \& Yeo 2015), an update is required given the dynamism of developments within the SCM field. The numerous SCM skills frameworks in the literature (Murphy \& Poist 1991; Trautrims, Defee \& Farris 2016; Wu et al. 2013) have not provided guidance to emerging academics and practitioners as to which framework is more appropriate for classifying SCM skills. 
Therefore, the problem can be defined as the fact that literature identifies many skills that are potentially required for effective SCM and furthermore describes a number of grouping frameworks, thereby creating confusion among practitioners and academics in terms of which skills and skills groups are most important when determining the skills required to ensure effective SCs. This calls for the harmonisation of SCM skills and their grouping into skill sets. Thus, this study aims to (1) identify and list as many as possible SCM skills from literature, (2) establish the existing SCM skills grouping frameworks in the literature and (3) propose a comprehensive SCM skills grouping framework for managers. The proposed SCM skills grouping framework sets the foundation for aligning and upgrading SCM skill sets.

\section{Supply chain management skills}

Supply chain management skills refer to competencies required for managing complex logistics operations and relationships (Mangan \& Christopher 2005; Murphy \& Poist 2007). Supply chain skills research has provided a large list of SCM skills, including SCM technical skills, business administration skills such as marketing, finance and human resource management, behavioural skills such as interpersonal skills, and management skills that are related to planning, organisation and control (Murphy \& Poist 1991, 2007).

Murphy and Poist (1991) presented a large list of 83 skills dominated by business- and management-related skills and only 18 logistics-specific skills. They argued that logistics skills required for senior managers are expected to enable them to coordinate cross-functional activities, as logistics impact other functions. Based on Murphy and Poist's (1991) list, Thai (2012) revised the skills from 83 to 68; however, the conclusions from his study validated the original study. The overall observation was that senior-level managers are required to be well equipped with management skills, although they also need to be well grounded in logistics knowledge areas to enter the field. According to Murphy and Poist (2006, 2007), future skills should have a supplier relationship management orientation and a focus on customer relationship management, which is also argued by Thai (2012).

Onar et al. (2013) examined graduate programmes delivered in 15 universities within Europe and identified 31 skills that are required by SC managers. They concluded that SC professionals should possess a variety of skills with an emphasis on hard SCM skills and less on soft skills. However, a work environment requires senior managers to be well equipped with soft skills to manage cross-functional operations for internal and external collaborations. For instance, Poist, Scheraga and Semeijn's (2001) study in Europe and the United States (US) concluded that an effective SCM professional should possess adequate general management skills, especially those related to communication, in addition to logistics functional skills. In a Singaporean and Malaysian study, Razzaque and Sirat (2001) identified 17 skills for logisticians and concluded that future SC managers must be multiskilled, as later confirmed by
Onar et al. (2013). Similarly, Keller and Ozment (2009) identified 17 skills that SC professionals at a managerial level should possess. However, they observed that skills related to general management, such as decision-making and problemsolving, were the dominant requirements, as also found by Thai (2012).

Mangan and Christopher (2005) argued that SCM managers require not only in-depth knowledge and skills in SCM but also skills and competencies to enable them to perform cross-functional operations. They identified analytical, interpersonal, leadership and change management as some of the skills for SCM managers. They further argued that SCM managers should have adequate knowledge of multimodal logistics, security and international trade, as also highlighted by Poist et al. (2001), as well as the ability to think in terms of processes and flows. In agreement with Mangan and Christopher (2005), Wu (2006) observed that SC managers should possess good communication skills, knowledge of finance, market analysis and IT, in addition to SCM industryspecific skills, such as maritime logistics. Heyns and Luke (2012) identified 38 skills, including customer service, teamwork, business ethics and core logistics skills, and environmental awareness. Cronjé (2015) also identified 25 functional and general management skills required by effective SC managers. He concluded that a balance between functional and technical SC skills categories is desirable.

It is observed that the studies examined hitherto reveal a wide and diverse range of SCM skills as illustrated in Table 1. Management-related skills, especially soft skills, have been put forward by many authors (Abreu \& Alcântara 2015; Dubey \& Gunasekaran 2015; Jordan \& Bak 2016; Murphy \& Poist 2007; Tatham et al. 2017) as essential in equipping SCM managers to perform their roles effectively and efficiently. Hard skills refer to SCM technical competencies that assist managers to perform their duties, while soft skills are those related to human interaction and behaviour (Dubey \& Gunasekaran 2015). Many other skills include those related to business administration and logistics. Therefore, there is a need to conduct an inventory of as many SCM skills as possible from the literature as the first step towards the standardisation and classification of skill names. A relatively comprehensive list of 270 logistics and SCM skills from the reviewed literature is presented in the Appendix 1 (see Figure 1-A1). Extant SC skills literature has also presented many skills groups with little or no consensus regarding the groups and skills in each group. In an attempt by this study to develop an SCM skills framework, the following methodology was followed.

\section{Methodology}

The purpose of this study was to identify and list as many SCM skills as possible from the literature, establish existing SCM skills frameworks from previous research and propose a comprehensive SCM skills grouping framework to guide managers. To meet this purpose, a systematic literature review (SLR) method was used to probe academic articles on SCM skills frameworks. The SLR method provides a 
TABLE 1: Supply chain management skills list.

\begin{tabular}{|c|c|c|c|c|c|c|c|c|c|c|c|c|}
\hline $\begin{array}{l}\text { Skills } \\
\text { group }\end{array}$ & Skills & $\begin{array}{l}\text { Murphy and } \\
\text { Poist (1991) }\end{array}$ & $\begin{array}{l}\text { Razzaque } \\
\text { and Sirat } \\
(2001)\end{array}$ & $\begin{array}{l}\text { Thai } \\
(2012)\end{array}$ & $\begin{array}{l}\text { Heyns and } \\
\text { Luke (2012) }\end{array}$ & $\begin{array}{l}\text { Wu et al. } \\
\text { (2013) }\end{array}$ & $\begin{array}{l}\text { Cronjé } \\
\text { (2015) }\end{array}$ & $\begin{array}{l}\text { Thai and Yeo } \\
\text { (2015) }\end{array}$ & $\begin{array}{l}\text { Sinha et al. } \\
\text { (2016) }\end{array}$ & $\begin{array}{l}\text { Tatham et al. } \\
\text { (2017) }\end{array}$ & $\begin{array}{l}\text { Rajakurana } \\
\text { et al. (2017) }\end{array}$ & $\begin{array}{l}\text { Kotzab et al. } \\
\quad(2018)\end{array}$ \\
\hline \multirow{26}{*}{$\begin{array}{l}\text { Hard SCM } \\
\text { skills }\end{array}$} & Cost control & - & - & $\checkmark$ & $\checkmark$ & $\checkmark$ & - & - & $\checkmark$ & - & - & - \\
\hline & Financial management & $\checkmark$ & $\checkmark$ & $\checkmark$ & - & $\checkmark$ & $\checkmark$ & $\checkmark$ & $\checkmark$ & $\checkmark$ & $\checkmark$ & \\
\hline & Planning & $\checkmark$ & $\checkmark$ & $\checkmark$ & $\checkmark$ & $\checkmark$ & $\checkmark$ & $\checkmark$ & $\checkmark$ & $\checkmark$ & $\checkmark$ & $\checkmark$ \\
\hline & Risk management & - & - & $\checkmark$ & - & $\checkmark$ & - & $\checkmark$ & $\checkmark$ & $\checkmark$ & $\checkmark$ & - \\
\hline & $\begin{array}{l}\text { Human resource } \\
\text { management }\end{array}$ & $\checkmark$ & - & $\checkmark$ & - & - & - & $\checkmark$ & - & $\checkmark$ & $\checkmark$ & - \\
\hline & Analysing statistical data & $\checkmark$ & $\checkmark$ & $\checkmark$ & $\checkmark$ & $\checkmark$ & $\checkmark$ & $\checkmark$ & - & - & - & $\checkmark$ \\
\hline & $\begin{array}{l}\text { Information system } \\
\text { management }\end{array}$ & $\checkmark$ & - & $\checkmark$ & $\checkmark$ & $\checkmark$ & $\checkmark$ & $\checkmark$ & $\checkmark$ & $\checkmark$ & $\checkmark$ & - \\
\hline & $\begin{array}{l}\text { Modelling of operations } \\
\text { systems }\end{array}$ & - & $\checkmark$ & $\checkmark$ & - & - & $\checkmark$ & $\checkmark$ & $\checkmark$ & - & - & - \\
\hline & $\begin{array}{l}\text { Understanding economic } \\
\text { principles }\end{array}$ & $\checkmark$ & - & $\checkmark$ & - & - & - & $\checkmark$ & - & - & - & - \\
\hline & Business regulations & $\checkmark$ & $\checkmark$ & $\checkmark$ & - & - & - & $\checkmark$ & - & $\checkmark$ & - & - \\
\hline & Marketing & $\checkmark$ & - & $\checkmark$ & - & $\checkmark$ & $\checkmark$ & $\checkmark$ & - & $\checkmark$ & $\checkmark$ & - \\
\hline & $\begin{array}{l}\text { International business } \\
\text { regulations }\end{array}$ & $\checkmark$ & - & $\checkmark$ & - & $\checkmark$ & - & $\checkmark$ & $\checkmark$ & - & $\checkmark$ & $\checkmark$ \\
\hline & Contract management & $\checkmark$ & $\checkmark$ & $\checkmark$ & - & - & - & $\checkmark$ & - & $\checkmark$ & $\checkmark$ & - \\
\hline & $\begin{array}{l}\text { Traffic/transport } \\
\text { management }\end{array}$ & $\checkmark$ & - & $\checkmark$ & $\checkmark$ & - & $\checkmark$ & $\checkmark$ & $\checkmark$ & $\checkmark$ & $\checkmark$ & - \\
\hline & $\begin{array}{l}\text { Understanding logistics } \\
\text { terminology }\end{array}$ & - & $\checkmark$ & $\checkmark$ & $\checkmark$ & - & & $\checkmark$ & - & - & - & - \\
\hline & Inventory control & $\checkmark$ & - & $\checkmark$ & $\checkmark$ & - & $\checkmark$ & $\checkmark$ & $\checkmark$ & $\checkmark$ & $\checkmark$ & - \\
\hline & $\begin{array}{l}\text { Planning the location of } \\
\text { facilities }\end{array}$ & - & $\checkmark$ & $\checkmark$ & $\checkmark$ & - & $\checkmark$ & - & $\checkmark$ & - & - & - \\
\hline & $\begin{array}{l}\text { Product demand } \\
\text { forecasting }\end{array}$ & $\checkmark$ & - & $\checkmark$ & $\checkmark$ & - & & $\checkmark$ & $\checkmark$ & $\checkmark$ & $\checkmark$ & - \\
\hline & Purchasing/procurement & $\checkmark$ & - & $\checkmark$ & $\checkmark$ & $\checkmark$ & & $\checkmark$ & $\checkmark$ & $\checkmark$ & $\checkmark$ & $\checkmark$ \\
\hline & Warehousing & $\checkmark$ & $\checkmark$ & $\checkmark$ & $\checkmark$ & $\checkmark$ & $\checkmark$ & $\checkmark$ & & $\checkmark$ & $\checkmark$ & - \\
\hline & International logistics & $\checkmark$ & $\checkmark$ & $\checkmark$ & & $\checkmark$ & $\checkmark$ & - & - & - & - & - \\
\hline & Reverse logistics & - & - & $\checkmark$ & $\checkmark$ & - & - & $\checkmark$ & $\checkmark$ & $\checkmark$ & $\checkmark$ & - \\
\hline & Packaging & $\checkmark$ & - & $\checkmark$ & - & - & - & $\checkmark$ & - & - & - & - \\
\hline & Problem-solving ability & $\checkmark$ & - & $\checkmark$ & $\checkmark$ & $\checkmark$ & $\checkmark$ & $\checkmark$ & $\checkmark$ & $\checkmark$ & - & - \\
\hline & Controlling & $\checkmark$ & $\checkmark$ & - & - & - & $\checkmark$ & $\checkmark$ & - & - & - & $\checkmark$ \\
\hline & Quantitative methods & $\checkmark$ & - & - & $\checkmark$ & - & $\checkmark$ & - & $\checkmark$ & - & - & $\checkmark$ \\
\hline \multirow[t]{11}{*}{$\begin{array}{l}\text { Soft SCM } \\
\text { skills }\end{array}$} & $\begin{array}{l}\text { Managing client } \\
\text { relationships }\end{array}$ & - & - & $\checkmark$ & - & - & $\checkmark$ & - & $\checkmark$ & $\checkmark$ & $\checkmark$ & - \\
\hline & Business ethics & $\checkmark$ & - & $\checkmark$ & $\checkmark$ & - & $\checkmark$ & - & $\checkmark$ & - & - & - \\
\hline & Customer service & $\checkmark$ & $\checkmark$ & $\checkmark$ & $\checkmark$ & - & - & $\checkmark$ & - & - & - & - \\
\hline & Communication & $\checkmark$ & $\checkmark$ & $\checkmark$ & $\checkmark$ & $\checkmark$ & $\checkmark$ & $\checkmark$ & $\checkmark$ & & $\checkmark$ & - \\
\hline & Negotiation & - & $\checkmark$ & $\checkmark$ & $\checkmark$ & $\checkmark$ & $\checkmark$ & $\checkmark$ & $\checkmark$ & $\checkmark$ & $\checkmark$ & - \\
\hline & Time management & $\checkmark$ & - & $\checkmark$ & $\checkmark$ & - & - & $\checkmark$ & - & - & - & - \\
\hline & People management & - & - & $\checkmark$ & - & $\checkmark$ & $\checkmark$ & - & - & $\checkmark$ & $\checkmark$ & - \\
\hline & Ability to organise & $\checkmark$ & - & $\checkmark$ & $\checkmark$ & - & $\checkmark$ & $\checkmark$ & - & - & - & - \\
\hline & Change management & $\checkmark$ & - & $\checkmark$ & $\checkmark$ & - & - & $\checkmark$ & $\checkmark$ & $\checkmark$ & $\checkmark$ & - \\
\hline & Leadership & - & - & - & $\checkmark$ & $\checkmark$ & $\checkmark$ & $\checkmark$ & $\checkmark$ & $\checkmark$ & $\checkmark$ & $\checkmark$ \\
\hline & Teamwork & - & - & - & $\checkmark$ & - & $\checkmark$ & - & $\checkmark$ & - & - & $\checkmark$ \\
\hline
\end{tabular}

Source: Abreu, A. \& Alcântara, R.L.C., 2015, 'Supply chain managers: Professional profile and the role in the cross-functional integration of supply chain management', Independent Journal of Management \& Production 6(1), viewed from http://www.ijmp.jor.br/index.php/ijmp/article/view/246; Dubey, R. \& Gunasekaran, A., 2015, 'Shortage of sustainable supply chain talent: An industrial training framework', Industrial and Commercial Training 47(2), 86-94, viewed from http://www.emeraldinsight.com/doi/10.1108/ICT-08-2014-0052.

SCM, supply chain management.

transparent guide for searching and assessing (Tian et al. 2018) relevant research in SCM skills framework.

The articles selected for this study were searched for in both aggregator and publisher databases to provide a comprehensive list regarding SCM skills framework research. The specific databases searched were Science Direct, Emerald, EBSCOhost, IEEE Xplore, Proquest, Springer, Taylor \& Francis, Wiley Online, Scopus and JSTOR. These databases have been used by SCM researchers in the past who have argued that they provided a most comprehensive list of peer-reviewed articles for an SLR methodology (Lima-Junior \& Carpinnetti 2017). As also claimed by Lima-Junior and Carpinnetti, peer-reviewed articles provided the most reliable materials explaining the concepts under investigation. The keywords used in the search were 'SCM skills', 'logistics skills', 'framework', and 'skills requirements'. Peer-reviewed articles from the 1990s to the present were selected for review. This is the period when the SCM research, as well as logistics and SCM as a discipline, has witnessed the highest levels of growth (Langley \& Infosys 2019; Murphy \& Poist 2007). The articles 


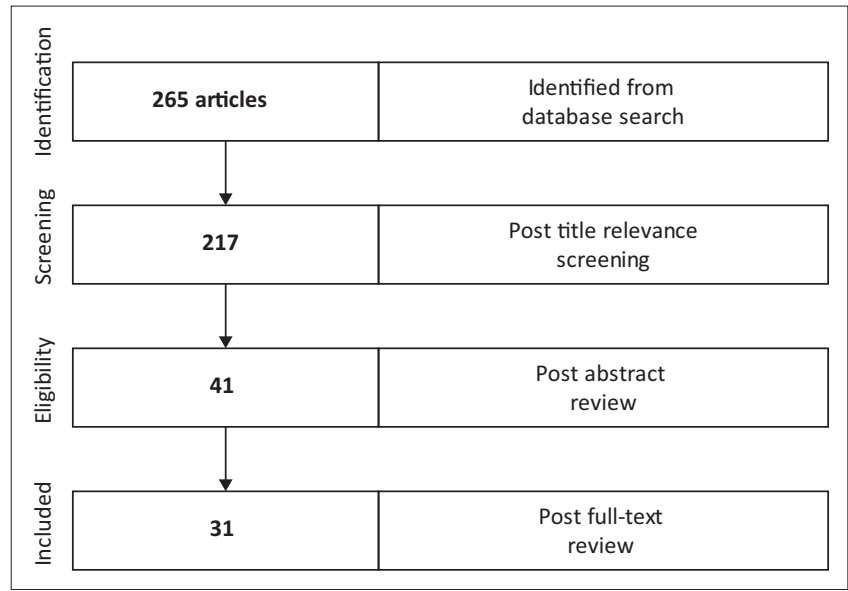

Source: Bastas, A. \& Liyanage, K., 2018, 'Sustainable supply chain quality management: A systematic review', Journal of Cleaner Production 181, 726-744. https://doi.org/10.1016/j. jclepro.2018.01.110.

FIGURE 1: An overview of the article selection process.

were selected from various categories, such as business, management, operations and management science. The selection process entailed first reading the abstract to determine the relevance of the article in relation to the research purpose. Thereafter, the article was included in the list if it was found to be relevant. Full-text searches of the selected articles were conducted, downloaded and reviewed in line with the research objectives. The research process followed in this study is illustrated in Table 2.

The search from the identified aggregator and publisher databases resulted in 265 articles. The selection of the final articles to be included in this study involved identification of the articles from the databases (265), screening by article title (217), reviewing abstracts to select eligible articles (41) and full-text review to finally select the articles to be included (31) in the analysis, as illustrated in Figure 1. It is noted that the SLR process was iterative in nature whereby articles were evaluated repeatedly before finally being included. The majority of the articles from the initial selection were excluded at the abstract evaluation step. In addition, diagonal reading was done whenever the abstract review did not provide enough information. This helped to ensure that only papers that contributed towards answering the main research question were included.

The qualitative data collected from the 31 selected articles were reviewed using frequencies and thematic synthesis. Frequencies analyses involved distribution of the number of articles per year of publication, methodology used, per journal, per university or institution of affiliation, per author, industry, research designs, and data analysis. The results were presented in tables and charts. Thematic analysis is used to integrate findings from multiple articles when conducting SLR (Thomas \& Harden 2008). It involved reading the selected full-text articles, generating codes and coding each of the articles regarding SCM skills using computer aided qualitative data analysis software known as Atlas.ti 8. Atlas.ti is a qualitative data analysis software that
TABLE 2: Research process.

\begin{tabular}{|c|c|}
\hline Steps & Description \\
\hline Step 1 & Research objectives \\
\hline \multirow{3}{*}{$\begin{array}{l}\text { Formulating } \\
\text { research } \\
\text { objectives }\end{array}$} & 1. To identify SCM skills list in literature \\
\hline & 2. To establish SCM skills grouping frameworks in literature \\
\hline & 3. To propose an SCM skills list and grouping framework for Africa \\
\hline Step 2 & Literature databases \\
\hline \multirow{14}{*}{$\begin{array}{l}\text { Locating, } \\
\text { selecting and } \\
\text { reviewing } \\
\text { articles }\end{array}$} & $\begin{array}{l}\text { Science Direct, Emerald, EBSCOhost, IEEE Xplore, Proquest, } \\
\text { Springer, Taylor and Francis, Wiley Online, Scopus and JSTOR. }\end{array}$ \\
\hline & Search period \\
\hline & $\begin{array}{l}1990 \text { to date: Period in which growth in logistics and SCM has been } \\
\text { witnessed globally (Murphy \& Poist 2007) }\end{array}$ \\
\hline & Inclusion criteria \\
\hline & $\begin{array}{l}\text { SCM skills, logistics management skills including skills frameworks } \\
\text { and development }\end{array}$ \\
\hline & Exclusion criteria \\
\hline & $\begin{array}{l}\text { Any logistics SCM skills development or frameworks outside } \\
\text { business management, operations or management science }\end{array}$ \\
\hline & Search strings \\
\hline & 'supply chain management skills' \\
\hline & 'supply chain management skills' + 'framework' \\
\hline & 'supply chain management skills' + 'requirements' \\
\hline & 'logistics management skills' \\
\hline & 'logistics management skills' + 'framework' \\
\hline & 'logistics management skills' + 'requirements' \\
\hline Step 3 & Method of analysis \\
\hline Analysis & Descriptive and content analysis \\
\hline
\end{tabular}

Source: Bastas, A. \& Liyanage, K., 2018, 'Sustainable supply chain quality management: A systematic review', Journal of Cleaner Production 181, 726-744. https://doi.org/10.1016/j. jclepro.2018.01.110.

SCM, supply chain management.

assists to analyse qualitative data. It was selected owing to its capability to allow a researcher to upload full-text documents, creating and managing codes based on content analysis, grouping the codes and finding relationships between the codes. Atlas.ti 8 also provided a user-friendly graphical interphace. The codes were examined to confirm that consistency was observed and, where necessary, additional coding was performed. The coding process resulted in 14 initial codes. Similarities and differences between the codes were examined to allow for grouping of the codes. The grouping of SCM skills resulted in six themes. The identified themes related to management, business, logistics IT, quantitative analysis, logistics and behavioural skills. The findings are presented in the next section.

\section{Ethical considerations}

This article followed all ethical standards for research without direct contact with human or animal subjects.

\section{Findings}

A total of 31 full-text articles published between 1990 and 2018 (Figure 2) were included in the analysis. Figure 2 reveals that 24 out of 31 articles (77\%) reviewed were published between 2010 and 2018, revealing higher growth in SC skills research in the latter part of the period.

The distribution of studies by research country (Figure 3) reveals that many of the studies reviewed were conducted in the US (six articles) followed by Australia (four articles) and Europe (three articles). The least represented countries with 
one article each included Brazil, South Africa, Zimbabwe and Finland. The distribution also revealed that multiple country studies revealing SC skills research collaborations were within Europe, Europe and US, Singapore and Malaysia as well as Singapore and South Korea. This indicates that the studies provide varied findings from both single country and multiple country studies. It also reveals that a lot more research has been done into SC skills in developed than developing countries, which represents a considerable gap in the literature. The distributions also reveal that the studies represent all five continents, giving a global perspective of SCM skills research.

The distribution of the studies in terms of the main research methodology applied is illustrated in Figure 4. The most popular method was survey research, accounting for slightly more than $35 \%$ of the studies. It is followed by mixed methods and content analysis at just below 20\%. The review method was applied in about $16 \%$ of the reviewed articles.

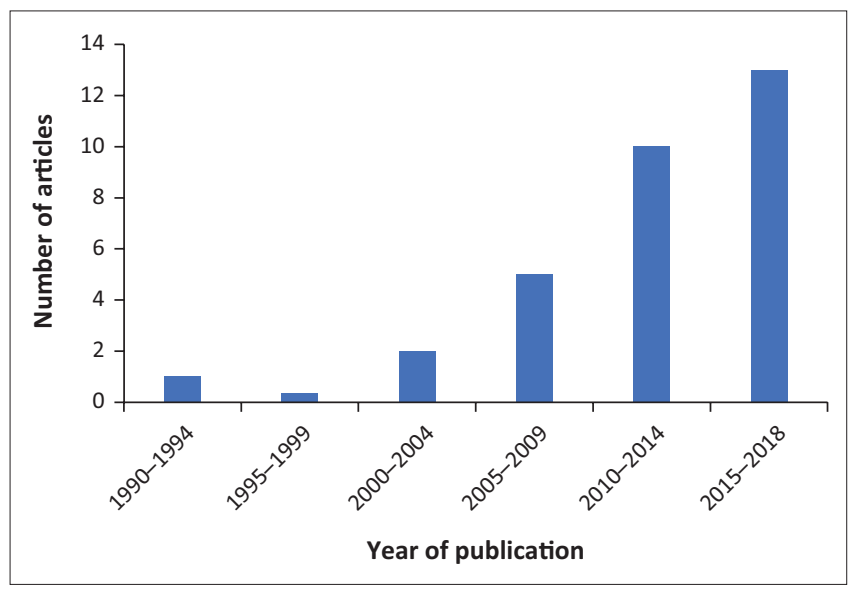

FIGURE 2: Number of articles reviewed and years of publication.
The conceptual research method was the least applied among the reviewed studies.

A distribution of the economic sectors where the studies' findings were applied are illustrated in Figure 5. Less than half of the studies reviewed were conducted in education, the logistics industry and manufacturing. However, $65.6 \%$ of the studies did not reveal the economic sectors studied. The large omission of the economic sectors studied in published research papers also represents a gap in the research and could be perceived as a disservice to practitioners, academics as well as general readers as different contexts may require different SCM skills.

A total of 79 active authors, including co-authors, contributed to the 31 reviewed articles. The six most active authors and their corresponding number of articles are shown in Table 3. All other authors contributed one article each.

The distribution of the data analysis techniques was investigated per article reviewed. Only two articles applied three methods to analyse data. Ten articles applied two data analysis techniques, while the rest applied one analysis method each. The number of times an analysis technique was applied including where it is used with other methods was tallied, and the results are presented in Figure 6. The most common analysis techniques included content analysis and descriptive statistics. This could imply that high-level statistical analysis is not widely performed among the reviewed papers.

A list of authors' affiliations is presented in Table 4. Author(s) from Iowa State University authored four articles, followed by those from John Carroll University who authored three,

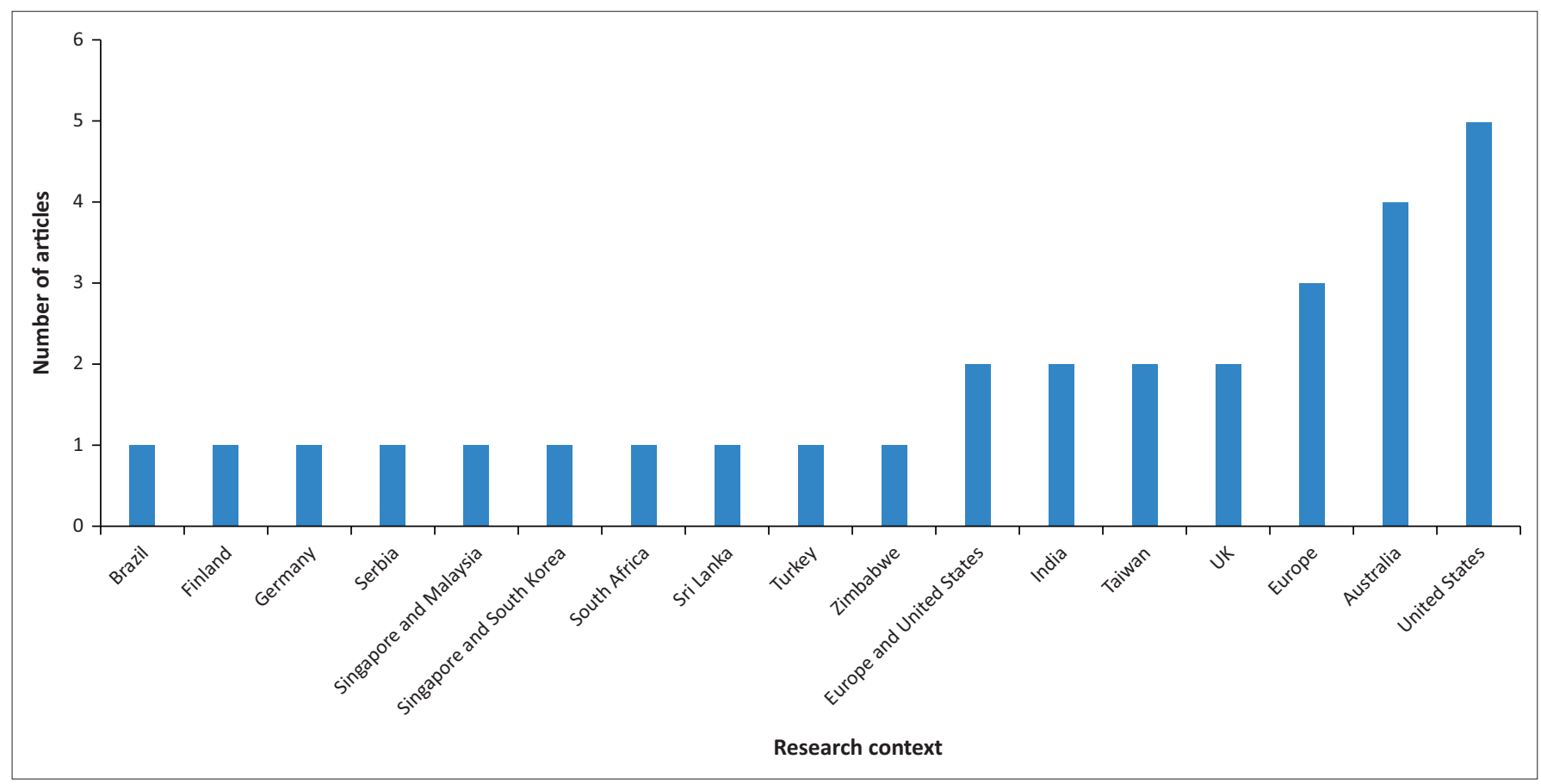

UK, United Kingdom.

FIGURE 3: Distribution of the number of reviewed articles by research context. 


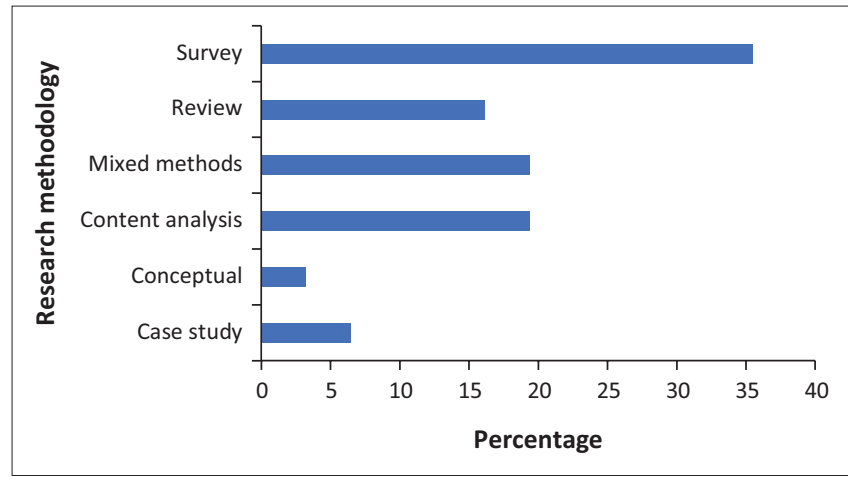

FIGURE 4: Research methodology and percentage of articles.

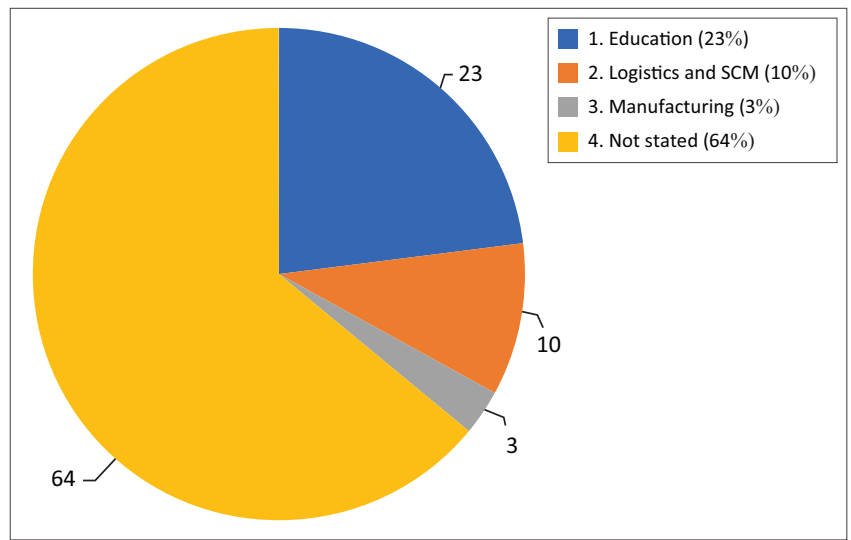

SCM, supply chain management.

FIGURE 5: Percentage distribution of the studies by industry or sector.

TABLE 3: Most active authors.

\begin{tabular}{lc}
\hline Author & Number of articles \\
\hline Richard Poist & 4 \\
Paul Murphy & 3 \\
Vihn Thai & 3 \\
Yeh-Chun Jim Wu & 2 \\
Rameshwar Dubey & 2 \\
Vinh Thai & 2 \\
\hline
\end{tabular}

while the majority of the researchers had authored a single article, with the University of Johannesburg and North-West University being the only affiliations from Africa. This could imply that, although there were indications of country collaborations, cross-country collaborations among authors is limited, especially in African institutions. In addition, the articles reviewed were published in a total of 17 peerreviewed journals as illustrated in Table 5 .

The key issue observed from analysis of the SC skills literature is that each author asserts that there are many skills that an SC manager is expected to possess; however, the authors have not established standard skills that an SC manager should possess. A list of the many SCM skills collected from the literature is presented in Figure 1-A1 in Appendix 1. The identified SCM skills remained relatively stable during the review period (1990-2018), with a few additions. The additions to Murphy and Poist's (1991) SCM skills list over the years include environmental awareness (Heyns \& Luke 2012; Onar et al. 2013; Thai, Cahoon \&

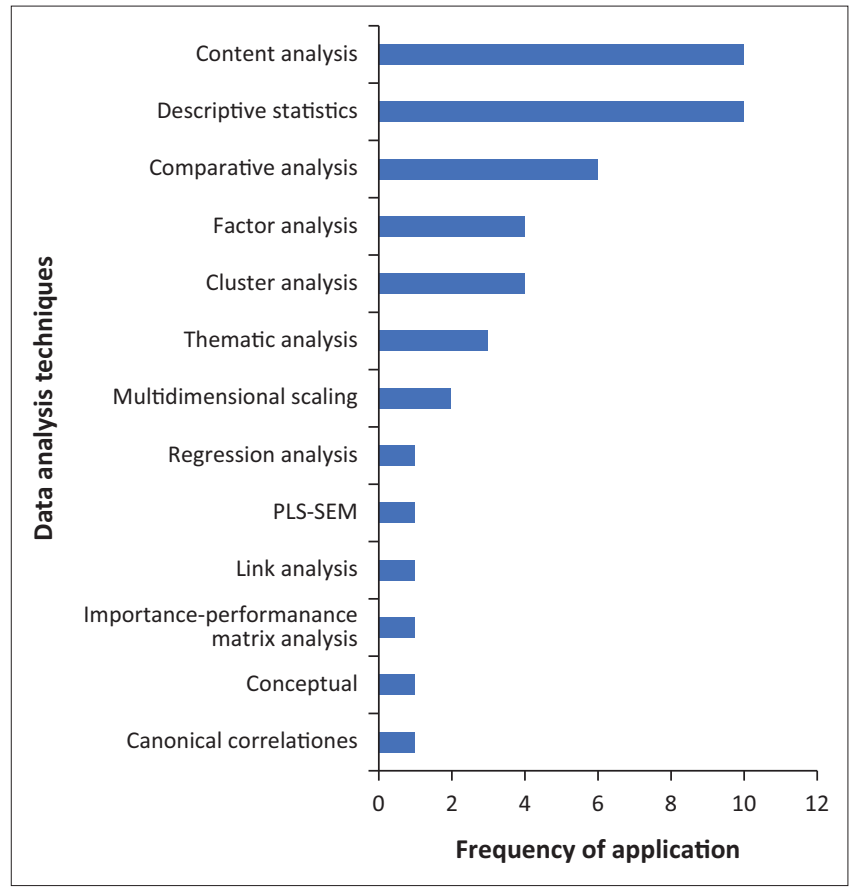

PLS-SEM, Partial least squares structural equation modelling. FIGURE 6: Data analysis techniques.

Tran 2011; Wu et al. 2013), international trade, including international finance for the purpose of managing global SCs (Murphy \& Poist 2006; Wu 2006), and risk management (Wu et al. 2013). Over the years there has also been an emphasis on skills that help SC managers coordinate interdepartmental as well as inter-organisational processes, given that SCM is boundary spanning (Heyns \& Luke 2012; Mangan \& Christopher 2005; Wu 2006). In addition, Kotzab et al. (2018) argued that SC managers are now required to have the ability to learn continuously to adapt to the dynamism of the SCM industry, owing to constant transformations through advanced information communications technologies. Skills related to logistics entrepreneurship and the ability to perform multiple functions which would imply flexibility of the SC manager are also desirable. Interestingly, SC managers are now often expected to be members of professional associations (Kotzab et al. 2018), which could imply that there is a standard set of knowledge and skills they are expected to possess to execute SC activities effectively. Notable also from the previous studies is that the traditional skills related to logistics such as transportation, warehousing, inventory, and procurement have been retained over the years. Contemporary SC managers are expected to be creative thinkers as well as have the ability to devise innovative plans for executing SCM processes (Rahman \& Qing 2014; Sinha et al. 2016). This is likely to help achieve the two polemic goals, viz. cost reduction and improved customer service levels in the SC. The key issue observed from the analysis of the SC skills literature is that each author asserts that there are many skills that an SC manager is expected to possess; however, the authors have not established standard skills that an SC manager should possess. 
TABLE 4: Authors' affiliation institutions.

\begin{tabular}{|c|c|}
\hline University & Number of papers \\
\hline lowa State University & 4 \\
\hline John Carroll University & 3 \\
\hline Cranfield University & 2 \\
\hline Nanyang Technological University & 2 \\
\hline RMIT University & 2 \\
\hline Symbiosis International University & 2 \\
\hline University of Massachusetts Dartmouth & 2 \\
\hline Baruch College & 1 \\
\hline Brunel University & 1 \\
\hline California State Polytechnic University & 1 \\
\hline Dalian Maritime University & 1 \\
\hline Deloitte Consulting LLP & 1 \\
\hline Fairfield University & 1 \\
\hline Federal University of São Carlos & 1 \\
\hline FOM University of Applied Sciences & 1 \\
\hline Griffith University & 1 \\
\hline Hanken School of Economics & 1 \\
\hline $\begin{array}{l}\text { Hochschule Fulda University of Applied } \\
\text { Sciences }\end{array}$ & 1 \\
\hline Hull University Business School & 1 \\
\hline Istanbul Technical University & 1 \\
\hline Izmir Institute of Technology & 1 \\
\hline Leeds University Business School & 1 \\
\hline National Chiao Tung University & 1 \\
\hline National Chung Hsing University & 1 \\
\hline $\begin{array}{l}\text { National Kaohsiung First University of } \\
\text { Science and Technology }\end{array}$ & 1 \\
\hline National Sun Yat-Sen University & 1 \\
\hline National University of Singapore & 1 \\
\hline North-West University & 1 \\
\hline NUS and University of South Australia & 1 \\
\hline Sabaragamuwa University of Sri Lanka & 1 \\
\hline Shanghai Institute of Foreign Trade & 1 \\
\hline Stirling Management School & 1 \\
\hline The University of Alabama & 1 \\
\hline University of Arkansas & 1 \\
\hline University of Belgrade & 1 \\
\hline University of Bremen & 1 \\
\hline University of Huddersfield & 1 \\
\hline University of Hull & 1 \\
\hline University of Incheon & 1 \\
\hline University of Johannesburg & 1 \\
\hline University of Maastricht & 1 \\
\hline University of Nottingham & 1 \\
\hline University of Reading & 1 \\
\hline University of Sussex & 1 \\
\hline University of Texas at Tyler & 1 \\
\hline University of Turku & 1 \\
\hline University of West Florida & 1 \\
\hline Westminster Business School & 1 \\
\hline
\end{tabular}

LLP, limited liability partnership; NSU, National students union.

Supply chain skills have been discussed under various frameworks, as established from literature. This causes more confusion to emerging academics in this area, as well as to SC practitioners. In fact, many similar skills have been categorised differently by authors, as previously established, resulting in many varied frameworks. For example, 83 SCM skills are grouped into three categories (Murphy \& Poist 1991), 38 skills are grouped into six categories (Heyns \& Luke 2012), 57 skills are grouped into seven (Wu 2006) and 68 skills are grouped into three categories (Thai 2012). Therefore, SC managers as
TABLE 5: Distribution of journals.

\begin{tabular}{lc}
\hline Journals & Number of articles \\
\hline Supply Chain Management: An International Journal & 7 \\
The International Journal of Logistics Management & 6 \\
International Journal of Physical Distribution \& Logistics & 3 \\
Management & \\
Journal of Transport and Supply Chain Management & 2 \\
Industrial and Commercial Training & 2 \\
Transportation Journal & 1 \\
Journal of Sustainable Business and Management Solutions in & 1 \\
Emerging Economies & \\
Journal of Humanitarian Logistics and Supply Chain Management & 1 \\
International Journal of Logistics Research and Applications & 1 \\
International Journal of Logistics Management & 1 \\
International Journal of Disaster Risk Reduction & 1 \\
Independent Journal of Management \& Production & 1 \\
\hline European Journal of Training and Development & 1 \\
Business, Management and Education & 1 \\
Benchmarking: An International Journal & 1 \\
\hline Asia Pacific Journal of Marketing and Logistics & 1 \\
\hline
\end{tabular}

well as academics might benefit from a harmonised SC skills framework which can be updated regularly to indicate new and emerging, as well as obsolete skills.

\section{Supply chain management skills and frameworks}

One of the objectives of this study is to establish the current SCM skills frameworks in the literature. Many studies (Heyns \& Luke 2012; Jordan \& Bak 2016; Murphy \& Poist 1991) have presented a variety of SCM skills frameworks, but no study so far has taken stock of these skills frameworks. This knowledge gap hinders furthering research on SCM regarding which skills are becoming obsolete, which need to be developed and which skills are emerging. Murphy and Poist (1991) presented the BLM framework in which SCM skills were classified into business, logistics and management with 33, 18 and 32 skills, respectively. Murphy and Poist (1991) concluded that logistics professionals should first possess management related skills, then logistics skills. The BLM framework was slightly modified and validated by Murphy and Poist (2006), new skills added included electronic commerce, SCM and entrepreneurship to the business group; recruit or hire, personal creativity, manage supplier relations and manage customer relations to the management group, while the logistics group remained static, with its original 18 skills. The modified BLM framework was validated by Murphy and Poist (2007) who concluded that future SC managers should possess more SCM skills related to supplier relationship management.

Some of the skills presented in the BLM frameworks that were initially regarded as separate skills can now be amalgamated, with the understanding that there are sufficient similarities in the skills set to be able to do so, for example, purchasing and procurement; negotiation and persuasion; decision-making ability and analytical thinking; transport and logistics and traffic or transport management (Thai et al. 2011). In the original BLM framework as well as the later 2006 
version, some skills were classed as a belonging to a particular skills set which now, as per current knowledge, belong to another, for example, procurement and transport and logistics were grouped as business skills while they are now understood to be part of the logistics skills group (Thai 2012). In addition, the BLM framework had only been tested in the US and there was a need for its validation in other environments. As such, Razzaque and Sirat (2001) tested it in Singapore and Malaysia. They grouped the 83 skills into subgroups whereby the business skills had six subgroups, namely, operational, basic knowledge, economics and finance, communication, legal knowledge, analytical and general knowledge skills, as illustrated in Table 6. The logistics and management skills groups were subdivided into four and six subgroups respectively. Skills related to communication and analytics were represented both in the business and management groups of the framework. The regrouping confirmed the duplication of skills in the BLM framework and encouraged the need to review it for the current and future application. Razzaque and Sirat (2001) argued that the BLM framework presented micro-level skills and proposes that the subgroups 'macro level skills' presented in Table 6 are more relevant, especially to SC executives.

Poist et al. (2001) and Razzaque and Sirat (2001) both found that broad based skill classifications were more relevant in identifying skills requirements for the SC. They investigated skills grouped as communication, adaptability, multidimensional capabilities, information systems and computer, leadership, interpersonal, management such as planning and control, technical strengths, technological literacy, quantitative, governmental relations and documentation proficiency. Both the studies of Poist et al. (2001) and Razzaque and Sirat (2001) concluded that SCM professionals should be management generalists first, thus confirming Murphy and Poist (1991). It is observed that the attempts by these studies to regroup the skills might be an indication of the lack of consensus on a universal logistics and SCM skills framework.

Mangan and Christopher (2005) investigated the skills profile for future logistics, and SCM professionals and proposed a T-shaped skills framework, as illustrated in Figure 7. They argued that logistics professionals should have an in-depth understanding of SCM-specific skills such as operations or SCM and processes and flows, as well as general skills (such as finance) and competencies (such as analytical) to allow for

TABLE 6: Subgroups of the business logistics management framework.

\begin{tabular}{lll}
\hline Business & Logistics & Management \\
\hline Operational & Storage and warehousing & General management \\
Basic business knowledge & Customer related & Strategic thinking abilities \\
Communication & International logistics & Personal qualities \\
Business law & Logistics planning & Negotiation \\
Analytical & - & Communication \\
General knowledge & - & Analytical \\
\hline
\end{tabular}

Source: Razzaque, M.A. \& Sirat, M.S., 2001, 'Skill requirements: Perception of the senior Asian logisticians', International Journal of Physical Distribution \& Logistics senior Asian logisticians', International Journal of Physical Distribution \& Logistics
Management 31(5), 374-395, viewed from http://www.emeraldinsight.com/doi/10.1108/ Management 31(5), $374-$.
09600030110395175 seamless cross-functional coordination. They concluded that the increasing complexity of SCM requires professionals grounded in logistics and SCM, as well as skilled in general management and competencies, thus supporting findings by Murphy and Poist (1991). The findings of Mangan and Christopher (2005) were later supported by Bölsche, Klumpp and Abidi (2013).

Although Rajakaruna et al. (2017) and Tatham et al.'s (2017) studies confirmed Mangan and Christopher's (2005) findings, Tatham et al. (2017) argued that logistics functional skills are critical for entry into the field, but management skills are more important for exploiting opportunities in the field.

Wu's (2006) framework had seven groups of 57 skills, namely, (1) networking/computing, (2) international trading/ procurement, (3) labour/customs/tax laws, (4) finance/cost control, (5) quantitative analysis, (6) planning/evaluation and (7) logistics centre operation skills. Wu argued that logistics professionals should possess logistics related skills for them to effectively orchestrate SC functions. To develop an optimal skills framework, Wu claimed that the seven groups can be classified further into skills requirements at basic, managerial and business level. Basic level refers to beginners in the logistics professional. The skills clusters required at the basic logistics level include computing, laws and distribution centre operations skills. At the managerial level logistics professionals are expected to possess skills related to finance/cost control, quantitative analysis, planning/evaluation and international trading/procurement in addition to the basic level skills clusters, as illustrated in Table 7. At the business level, logistics professionals are

\begin{tabular}{|c|c|c|}
\hline $\begin{array}{c}\text { General skills/ } \\
\text { knowledge } \\
\text { Finance; IT and } \\
\text { management/strategy }\end{array}$ & $\begin{array}{l}\text { Logistics/SCM } \\
\text { specific } \\
\text { - Operations/SCM } \\
\text { - Processes and } \\
\text { flows } \\
\text { - Legal, security and } \\
\text { international trade } \\
\text { - Multimodal logistics }\end{array}$ & $\begin{array}{c}\text { Competencies/skills } \\
\text { Analytical; leadership; } \\
\text { interpersonal; change } \\
\text { management; project } \\
\text { management }\end{array}$ \\
\cline { 3 - 4 }
\end{tabular}

Source: Mangan, J. \& Christopher, M., 2005, 'Management development and the supply chain manager of the future', The International Journal of Logistics Management 16(2), 178-191, viewed from http://www.emeraldinsight.com/doi/10.1108/09574090510634494 SCM, Supply chain management; IT, information technology.

SCM, supply chain management.

FIGURE 7: T-shaped skills framework.

TABLE 7: Expertise level skills requirements.

\begin{tabular}{lll}
\hline Basic level & Managerial level & Business level \\
\hline Networking/computing & Networking/computing & $\begin{array}{l}\text { International trading/ } \\
\text { procurement }\end{array}$ \\
Labour/customs/tax laws & $\begin{array}{l}\text { International trading/ } \\
\text { procurement }\end{array}$ & Finance/cost control \\
Logistics centre operation skills & $\begin{array}{l}\text { Labour/customs/tax laws } \\
\text { Finance/cost control }\end{array}$ & $\begin{array}{l}\text { Quantitative analysis } \\
\text { Planning/evaluation }\end{array}$ \\
& $\begin{array}{l}\text { Quantitative analysis } \\
\text { Planng/evaluation }\end{array}$ & - \\
& Logistics centre operation \\
skills & - \\
\hline
\end{tabular}

Source: Wu, Y., 2006, 'Skill requirements for logistics license in Taiwan', Supply Chain Management: An International Journal 11(5), 415-424, viewed from http://www. emeraldinsight.com/doi/10.1108/13598540610682435. 
expected to possess high level skills related to international trading/procurement, finance/cost control, quantitative analysis and planning/evaluation in that order. This confirms previous studies that held that SCM managers should have both general management and logistics skills to effectively orchestrate SC functions (Murphy \& Poist 2006; Thai 2012).

A modified BLM framework (BLM version 2) was developed and validated by Thai et al. (2011) in Australia. Thai et al. (2011) deleted 13 skills, combined two, reworded some and added seven additional skills to the business group, thus modifying it from 33 skills in the original BLM framework to 25 skills. The additions included knowledge of client systems, impact of globalisation, managing culture, risk management, impact of climate change and occupational health and safety. The logistics skills group, after regrouping, consisted of 20 skills and three new skills totalling 23 skills. The additions were understanding logistics terminology owing to the growth in global logistics, engineering logistics and environmentally sustainable logistics to counter negative effects of climate change (Thai 2012; Thai et al. 2011). Skills in the management group were reduced to 20 from the initial 32. The BLM 2 framework had a total of 68 skills (Thai 2012). Thai (2012) concluded that SCM professionals should be managers first before being logisticians, as also found by Murphy and Poist (1991, 2006), however the importance of logistics skills is likely to be high in the future.

Heyns and Luke (2012) investigated SC skills requirements in South Africa using a list of 66 skills which were considered important for managers by previous studies. The skills were examined by a panel of experts and resulted in 38 skills grouped into general management (5), behavioural/ interpersonal (12), logistics awareness (6), logistics analytical (10), logistics IT (3) and environmental awareness (2 skills). Logistics awareness, general management and interpersonal skills, which are critical in cross-functional coordination, were among the top skills groups for SC professionals in South Africa (Heyns \& Luke 2012), thus supporting Mangan and Christopher (2005). Similarly, Rahman and Qing (2014) examined 41 SCM skills, which were grouped into general management (15), analytical (14), IT (7) and environmental (5) skills groups. They concluded that SCM professionals should possess more general management and less analytical and ITrelated skills, as also claimed by Murphy and Poist (1991).

Supply chain skills have also been grouped previously based on the academic modules offered in tertiary institutions. For instance, Onar et al. (2013) investigated SC academic programmes in Europe and developed a knowledge and skills framework. The framework was divided into nine broad knowledge and skills areas which include SC management with seven skills, management (four), quantitative methods (five), information system/IT (four), marketing, finance/ economy (three), law and soft skills (four). Onar et al. (2013) observed that SC professionals should be grounded in logistics knowledge areas, as also found in Mangan and Christopher (2005). On the other hand, Wu et al. (2013) examined 50 skills to develop a skills framework for a global SC professional. Their study resulted in nine skills groups, which were different from the BLM framework. The skills groups were personal skills, leadership skills, internationalisation, logistics, information integration, market trends, international finance and trade, risk and profit management and environmental protection. They concluded that a global SCM professional requires knowledge in internationalisation, international finance and business laws as opposed to traditional logistics skills.

Lorentz et al. (2013) argued that a competence-performance improvement skills framework is likely to present a list of SCM skills to prioritise within an organisation. They divided the skills into clusters 1, 2 and 3, as illustrated in Table 8.

Clusters 1 and 2 skills should be accorded priority for development within the firm, and cluster 3 should be developed last, implying that skills connecting the firm's processes to customers and suppliers such as sourcing and supplier management and production planning and control need to be the priority within the organisation (Lorentz et al. 2013). The finding is related to prior studies, which claimed that logistics professionals should be managers first, then logisticians (Murphy \& Poist 1991, 2006, 2007; Wu 2006; Wu et al. 2013). Similarly, Wong et al. (2014) claimed that only skills which are required in the job market should be prioritised and developed at the workplace, as well as at educational institutions. They claimed that SC managers require more business management, leadership and professional skills and less specialised logistics skills to perform their duties (Wong et al. 2014).

Jordan and Bak (2016) identified seven groups of SCM skills acquired by graduates including strategic, behavioural, process management, quantitative, people management, decision-making and negotiation. In addition, they found the most important skills to SCM professionals include behavioural, decision-making and people management related skills. Another study by Sinha et al. (2016) claimed that SC knowledge and skills can be grouped according to the job requirements such as plan (for example, demand forecasting), source - raw materials planning and contract management, make - production management, deliver transportation and warehousing and enable - IT- and industry-specific knowledge. The findings support earlier

TABLE 8: Competence-performance improvement skills framework.

\begin{tabular}{lll}
\hline Cluster $\mathbf{1}$ & Cluster $\mathbf{2}$ & Cluster $\mathbf{3}$ \\
\hline $\begin{array}{l}\text { Sourcing and supplier } \\
\text { management }\end{array}$ & $\begin{array}{l}\text { Production planning and } \\
\text { control }\end{array}$ & $\begin{array}{l}\text { Research and development } \\
\text { and product launch }\end{array}$ \\
$\begin{array}{l}\text { Demand forecasting and } \\
\text { supply planning }\end{array}$ & $\begin{array}{l}\text { Customer and distribution } \\
\text { channel management } \\
\text { Information system for } \\
\text { logistics and production } \\
\text { control }\end{array}$ & $\begin{array}{l}\text { Inventory management } \\
\end{array}$ \\
& &
\end{tabular}

International logistics

Source: Lorentz, H., Töyli, J., Solakivi, T. \& Ojala, L., 2013, 'Priorities and determinants for Source: Lorentz, H., Toyli, J., Solakivi, T. \& Ojala, L., 2013, 'Priorities and determinants for
supply chain management skills development in manufacturing firms', Supply Chain Management: An International Journal 18(4), 358-375, viewed from http://www. emeraldinsight.com/doi/10.1108/SCM-03-2012-0111. 
studies by Mangan and Christopher who concluded that future SC professionals should possess skills related to crossfunctional coordination.

A lean classification of SC skills offered by Cvetić, Vasiljević and Danilović (2017) identified 15 professional and 14 fundamental competencies for an SC manager. The professional competencies include performance management and transport management, supplier relationship management, while fundamental competencies include communication, problem-solving and interpersonal skills (Cvetić et al. 2017). They also concluded that an effective SC manager should possess both the professional and fundamental skills. In addition, Kotzab et al. (2018), after an analysis of 280 skills related to logistics management job postings, concluded that, contrary to the literature, logistics professionals require more cognitive and meta-competences and fewer social skills. They defined cognitive competences to include problem-solving skills; meta-competences include the ability to learn continuously and social competences generally refer to interpersonal skills such as communication.

In summary, Table 9 illustrates the dominant SCM skills frameworks reviewed.

\section{Proposed supply chain management skills grouping framework}

Supply chain skills have been categorised differently by different authors in the logistics field (Kotzab et al. 2018). Some are based on SC education and training (Jordan \& Bak 2016), competences (Kotzab et al. 2018), developing competitiveness (Tatham et al. 2017), and specific industry requirements (Rajakaruna et al. 2017). The existing skills frameworks have focused on developing SC skills to address current SC challenges (Ellinger \& Ellinger 2014; Wu 2006). However, SC transformations are taking place at a rapid rate, with the increased application of advanced technologies such as unmanned air vehicles to complete deliveries, blockchain technologies and application of artificial intelligence in warehousing. Furthermore, the pivotal role of SCM for a firm's competitiveness has been recognised and is likely to increase in the future (Ellinger \& Ellinger 2014; Langley \& Infosys 2019). As such, it is important that an SC skills framework is developed to help harmonise skills requirements of contemporary and future SC managers.

The SC skills identified from the reviewed full-text articles were critically assessed and grouped into 14 codes. Similarities between the codes were identified and grouped, as per literature, into five core code groups, that is, management (two codes), behavioural (two codes), business (five codes), ethics and environment (two code) and logistics management (three codes), as illustrated in Table 10. The five code groups were derived based on the skills families. The five code groups were further refined by incorporating behavioural skills into the management group, in line with existing literature (Murphy \& Poist 1991; Razzaque \& Sirat
2001; Thai 2012; Wu et al. 2013), reducing them to four major codes. According to Kotzab et al. (2018) and Wu (2006), SC skills requirements differ per expertise level, that is, at basic or entry level, managerial and business or executive level. The skills framework proposed in this study is relevant for SC manager level. The uniqueness of the proposed framework is that it is gleaned from previous literature unlike the existing frameworks which are based on single studies. This implies that the proposed new framework is more informative as it combines the knowledge of the existing frameworks to present a tool that can guide SC managers in terms of SCM skills. An explanation of each of the proposed skills groups and some specific skills is provided in the following paragraphs.

\section{Management skills group}

Supply chain skills related to management have been of importance since the Murphy and Poist's (1991) framework. Management skills comprise characteristics such as the ability of the logistics manager to plan, organise and control, as well as soft skills such as team leadership and effective communication (Kotzab et al. 2018; Murphy \& Poist 1991; Thai 2012). The inclusion of this skills group supports Abreu and Alcântara's (2015) finding who argued that a future SC manager should possess skills related to change management, communication, collaboration and partnering, and leadership to help coordinate cross-functional activities. Further, Rahman and Qing (2014) observed that the management skills group can include analytical and information-sharing skills. Many researchers agree that SC managers should possess additional management-related skills such as negotiation, effective team leadership, cost management and people management (Murphy \& Poist 1991, 2006; Thai 2012; Thai et al. 2011; Thai \& Yeo 2015; Wu 2006; Wu et al. 2013). In addition, Yildiz (2015) argued that an SC manager should be able to solve complex problems, be a critical thinker, innovative, communicate effectively and be a good planner, which is in agreement with Heyns and Luke (2012), Rahman and Qing (2014) and Sinha et al. (2016). Therefore, based on the literature reviewed, the skills related to the behavioural code group were combined with management to form the management group in the proposed skills grouping framework (see Figure 8).

\section{Business skills group}

Business skills encompass knowledge areas that pertain to business administrations such as economics, accounting, finance, and marketing (Murphy \& Poist 1991; Onar et al. 2013; Razzaque \& Sirat 2001). Business skills have a direct impact on business operations, thus enabling business process improvements (Murphy \& Poist 1991; Onar et al. 2013). There is consensus among researchers that SC managers should possess accounting and finance skills to help them control cost and make the right decisions regarding the economic contribution of SCM to an organisation (Murphy \& Poist 1991; Tahtham et al. 2017; Thai et al. 2011). 
TABLE 9: Supply chain skills frameworks.

\begin{tabular}{|c|c|c|c|c|}
\hline Author(s) & $\begin{array}{c}\text { Number of } \\
\text { skills identified }\end{array}$ & Identified framework & Skill groups & Remarks \\
\hline $\begin{array}{l}\text { Murphy and Poist } \\
(1991,2006,2007)\end{array}$ & 83 & $\begin{array}{l}\text { Business logistics } \\
\text { management framework }\end{array}$ & $\begin{array}{l}\text { Business skills } \\
\text { Logistics skills } \\
\text { Management skills }\end{array}$ & $\begin{array}{l}\text { Management skills are most important, followed } \\
\text { by logistics skills }\end{array}$ \\
\hline $\begin{array}{l}\text { Thai (2012) and } \\
\text { Thai et al. (2011) }\end{array}$ & 68 & $\begin{array}{l}\text { Modified business } \\
\text { logistics management } \\
\text { framework }\end{array}$ & $\begin{array}{l}\text { Business } \\
\text { Logistics } \\
\text { Management }\end{array}$ & $\begin{array}{l}\text { Validated the BLM framework } \\
\text { Claimed that future training is needed to focus on } \\
\text { logistics skills, for example, CRM, problem-solving, } \\
\text { cost control }\end{array}$ \\
\hline Onar et al. (2013) & 31 & Focused and diversified & $\begin{array}{l}\text { Supply chain management } \\
\text { Management } \\
\text { Quantitative methods } \\
\text { Marketing } \\
\text { Information technology } \\
\text { Finance } \\
\text { Law } \\
\text { Soft skills }\end{array}$ & $\begin{array}{l}\text { As educators focus on SCM skills, they should also } \\
\text { offer diversified skills in areas of management and } \\
\text { quantitative. Emphasis is on SCM skills across } \\
\text { Europe }\end{array}$ \\
\hline Poist et al. (2001) & 12 & $\begin{array}{l}\text { International supply chain } \\
\text { management }\end{array}$ & $\begin{array}{l}\text { General management, communication, } \\
\text { functional, quantitative and interpersonal skills }\end{array}$ & $\begin{array}{l}\text { Management skills are most important, followed } \\
\text { by functional skills }\end{array}$ \\
\hline $\begin{array}{l}\text { Razzaque and Sirat } \\
\text { (2001) }\end{array}$ & 17 & $\begin{array}{l}\text { Business logistics } \\
\text { management framework }\end{array}$ & $\begin{array}{l}\text { Business skills/knowledge } \\
\text { Logistics skills/knowledge } \\
\text { Managerial skills/knowledge }\end{array}$ & $\begin{array}{l}\text { Validated the BLM framework. } \\
\text { Effective logisticians need to be multiskilled, for } \\
\text { example, managerial, functional and interpersonal } \\
\text { skills }\end{array}$ \\
\hline $\begin{array}{l}\text { Mangan and } \\
\text { Christopher (2005) }\end{array}$ & 13 & T-shaped skills profile & $\begin{array}{l}\text { General } \\
\text { Logistics/SCM-specific competencies/skills }\end{array}$ & $\begin{array}{l}\text { Logisticians need in-depth knowledge and skills in } \\
\text { the functional area and multiple skills to manage } \\
\text { cross-functional operations }\end{array}$ \\
\hline Wu (2006) & 57 & $\begin{array}{l}\text { Expertise level framework } \\
\text { (basic, managerial and } \\
\text { business levels) }\end{array}$ & $\begin{array}{l}\text { Networking/computing } \\
\text { International trading/procurement } \\
\text { Labour/customs/tax laws } \\
\text { Finance/cost control } \\
\text { Quantitative analysis } \\
\text { Planning/evaluation } \\
\text { Logistics centre operation skills }\end{array}$ & $\begin{array}{l}\text { Logistics centre operation skills are to be } \\
\text { emphasised at managerial and basic training levels }\end{array}$ \\
\hline $\begin{array}{l}\text { Heyns and Luke } \\
(2012)\end{array}$ & 38 & $\begin{array}{l}\text { supply chain } \\
\text { management professional }\end{array}$ & $\begin{array}{l}\text { Logistics awareness } \\
\text { General management } \\
\text { Behavioural/interpersonal skills } \\
\text { Logistics analytical } \\
\text { Logistics IT } \\
\text { Environmental awareness }\end{array}$ & $\begin{array}{l}\text { Overall logistics awareness skills were found to be } \\
\text { most important. Skills related to interpersonal } \\
\text { skills were ranked among the important skills }\end{array}$ \\
\hline Wu et al. (2013) & 50 & $\begin{array}{l}\text { Business logistics } \\
\text { management }\end{array}$ & $\begin{array}{l}\text { Personal } \\
\text { Leadership } \\
\text { Internationalisation } \\
\text { Logistics } \\
\text { Information integration } \\
\text { Market trends } \\
\text { International finance } \\
\text { Risk and profit management } \\
\text { Environmental protection }\end{array}$ & $\begin{array}{l}\text { Cross-functional skills are most risky and financial } \\
\text { management }\end{array}$ \\
\hline $\begin{array}{l}\text { Lorentz et al. } \\
\text { (2013) }\end{array}$ & 12 & $\begin{array}{l}\text { Competence- } \\
\text { performance } \\
\text { improvement framework }\end{array}$ & $\begin{array}{l}\text { Cluster } 1 \text { - demand forecasting and supply } \\
\text { planning; sourcing and supplier management. } \\
\text { Cluster } 2 \text { - production planning and control; } \\
\text { customer and distribution channel } \\
\text { management; IS logistics and production } \\
\text { control. } \\
\text { Cluster } 3 \text { - R and D and new product launch; } \\
\text { inventory management; transport; international } \\
\text { logistics }\end{array}$ & $\begin{array}{l}\text { Identified top skills to be prioritised as those } \\
\text { connecting the supplier and customer to the firm's } \\
\text { processes, for example, demand forecasting and } \\
\text { supply planning, and information systems for } \\
\text { logistics }\end{array}$ \\
\hline $\begin{array}{l}\text { Bölsche, et al. } \\
\text { (2013) }\end{array}$ & 34 & T-shaped & $\begin{array}{l}\text { Functional skills } \\
\text { General management skills }\end{array}$ & $\begin{array}{l}\text { Effective logisticians need to be multiskilled, for } \\
\text { example, managerial, functional and interpersonal } \\
\text { skills. Inter-organisational skills are most } \\
\text { important. Skills were classified into demand } \\
\text { forecasting and planning, customer and } \\
\text { distribution channel management and R and D } \\
\text { and new product launch }\end{array}$ \\
\hline Wong et al. (2014) & 15 & Industry prioritised skills & $\begin{array}{l}\text { Professional skills } \\
\text { Finance, accounting and economics } \\
\text { Business management } \\
\text { Leadership } \\
\text { Logistics, operations and supply chain } \\
\text { Analytical skills }\end{array}$ & $\begin{array}{l}\text { Emphasise on management skills, teamwork and } \\
\text { leadership skills, over logistics and SCM core skills. } \\
\text { The study supports Murphy and Poist (1991) }\end{array}$ \\
\hline $\begin{array}{l}\text { Rahman and Qing } \\
\text { (2014) }\end{array}$ & 41 & $\begin{array}{l}\text { Supply chain } \\
\text { management skills }\end{array}$ & $\begin{array}{l}\text { General management } \\
\text { Analytical } \\
\text { Information technology } \\
\text { Environmental }\end{array}$ & $\begin{array}{l}\text { Supply chain general management skills were } \\
\text { most important }\end{array}$ \\
\hline $\begin{array}{l}\text { Thai and Yeo } \\
\text { (2015) }\end{array}$ & 63 & $\begin{array}{l}\text { Modified business } \\
\text { logistics management } \\
\text { framework }\end{array}$ & $\begin{array}{l}\text { Business related: Generalist and maritime } \\
\text { specific } \\
\text { Logistics related: Generalist, port-specific and } \\
\text { shipping specific } \\
\text { Management related: Generalist and maritime } \\
\text { specific }\end{array}$ & $\begin{array}{l}\text { Competent maritime logisticians need to acquire } \\
\text { general logistics and management skills before } \\
\text { in-depth logistics skills and knowledge }\end{array}$ \\
\hline $\begin{array}{l}\text { Dubey and } \\
\text { Gunasekaran } \\
\text { (2015) }\end{array}$ & 13 & $\begin{array}{l}\text { Hard and Soft skills } \\
\text { framework }\end{array}$ & $\begin{array}{l}\text { Hard and soft skills for sustainability; } \\
\text {-green logistics } \\
\text {-innovation } \\
\text {-complex problem-solving } \\
\text {-continuous learning ability }\end{array}$ & $\begin{array}{l}\text { Professionals should possess environment-related } \\
\text { skills. Logistics managers should possess soft and } \\
\text { hard skills to manage a sustainable supply chain as } \\
\text { per TBL }\end{array}$ \\
\hline
\end{tabular}


TABLE 9 (Continues...): Supply chain skills frameworks.

\begin{tabular}{|c|c|c|c|c|}
\hline Author(s) & $\begin{array}{c}\text { Number of } \\
\text { skills identified }\end{array}$ & Identified framework & Skill groups & Remarks \\
\hline Cronjé (2015) & 25 & Functional and General & $\begin{array}{l}\text { Core logistics and supply chain management } \\
\text { and general management }\end{array}$ & $\begin{array}{l}\text { Logistics and supply chain professionals possess } \\
\text { more of functional skills and less of general } \\
\text { management skills }\end{array}$ \\
\hline $\begin{array}{l}\text { Dubey and } \\
\text { Gunasekaran } \\
\text { (2015) }\end{array}$ & 11 & $\begin{array}{l}\text { Hard and soft skills } \\
\text { framework }\end{array}$ & $\begin{array}{l}\text { Business skills } \\
\text { Interpersonal } \\
\text { Communication } \\
\text { Conflict management } \\
\text { Leadership } \\
\text { Creativity } \\
\text { Business ethics }\end{array}$ & Supply chain talent \\
\hline $\begin{array}{l}\text { Jordan and Bak } \\
\text { (2016) }\end{array}$ & 25 & Graduate skills framework & $\begin{array}{l}\text { Strategic management } \\
\text { Process management } \\
\text { People management } \\
\text { Decision-making } \\
\text { Behavioural } \\
\text { Quantitative } \\
\text { Negotiation }\end{array}$ & $\begin{array}{l}\text { Emphasis on behavioural, decision-making and } \\
\text { people management skills }\end{array}$ \\
\hline $\begin{array}{l}\text { Trautrims et al. } \\
\text { (2016) }\end{array}$ & 8 & $\begin{array}{l}\text { Hard and Soft skills } \\
\text { framework }\end{array}$ & $\begin{array}{l}\text { Soft skills } \\
\text { Hard skills }\end{array}$ & $\begin{array}{l}\text { Emphasis should be on soft skills to allow for } \\
\text { inter-organisational collaboration }\end{array}$ \\
\hline Cvetić et al. (2017) & 29 & Functional and general & $\begin{array}{l}\text { Professional skills } \\
\text { Fundamental/general management skills }\end{array}$ & $\begin{array}{l}\text { Effective logistics and supply chain managers } \\
\text { should possess both professional and fundamental } \\
\text { skills }\end{array}$ \\
\hline $\begin{array}{l}\text { Rajakaruna et al. } \\
\text { (2017) }\end{array}$ & 26 & T-shaped skills profile & $\begin{array}{l}\text { Logistics management } \\
\text { Interpersonal skills } \\
\text { Supply chain coordination } \\
\text { Humanitarian logistics disaster management }\end{array}$ & $\begin{array}{l}\text { Humanitarian logisticians should have knowledge } \\
\text { related to general management, logistics core, } \\
\text { interpersonal skills and specific humanitarian } \\
\text { logistics skills }\end{array}$ \\
\hline $\begin{array}{l}\text { Tatham et al. } \\
\text { (2017) }\end{array}$ & 32 & T-shaped skills profile & $\begin{array}{l}\text { Functional skills } \\
\text { General management skills } \\
\text { Interpersonal skills } \\
\text { Problem-solving skills }\end{array}$ & $\begin{array}{l}\text { Emphasis on management/relational skills in } \\
\text { turbulent times (validated by Mangan \& } \\
\text { Christopher 2005) }\end{array}$ \\
\hline Kotzab et al. (2018) & 280 & $\begin{array}{l}\text { Competence-based } \\
\text { framework }\end{array}$ & $\begin{array}{l}\text { Sense of initiative and entrepreneurial } \\
\text { Social and civic } \\
\text { Cultural awareness } \\
\text { Mathematical and basic natural sciences } \\
\text { Advanced computer } \\
\text { Basic computer } \\
\text { Language } \\
\text { Learning to learn } \\
\text { Social competences } \\
\text { Functional competences } \\
\text { Cognitive competences } \\
\text { Meta-competences }\end{array}$ & $\begin{array}{l}\text { Logistics and supply chain professionals require } \\
\text { more of cognitive and meta-competences and less } \\
\text { of social competences }\end{array}$ \\
\hline
\end{tabular}

SCM, supply chain management; BLM, business logistics management; IT, information technology; CRM, customer relationship management; TBL, triple bottom line; IS, information system.

\section{TABLE 10: Code book.}

\begin{tabular}{ll}
\hline Code group & Codes \\
\hline Behavioural & Communication and interpersonal \\
Business skills & $\begin{array}{l}\text { Business administration, international business, legal, } \\
\text { quantitative skills, economics and finance }\end{array}$ \\
$\begin{array}{l}\text { Ethics and environment } \\
\text { Logistics }\end{array}$ & $\begin{array}{l}\text { Ethics and environmental } \\
\text { Information technology, logistics and risk management }\end{array}$ \\
\hline Management & General management and HRM \\
\hline
\end{tabular}

HRM, human resource management.

Based on the literature reviewed, customer focus or marketing skills help managers understand various customer segments and their requirements and plan to meet the identified needs (Cronjé 2015; Thai et al. 2011), as such, this skill was retained in the proposed framework. Skills related to laws and regulations, which include contract management with suppliers, customers and government agencies, are also key enablers of business operations, and every SC manager should be well versed therein (Rajakaruna et al. 2017; Wong et al. 2014). National and international laws are especially important for SC managers, given the current global nature of SCM (Murphy \& Poist 2007; Tatham et al. 2017).

Supply chain management as a function has grown tremendously, partly because of the advancement in IT

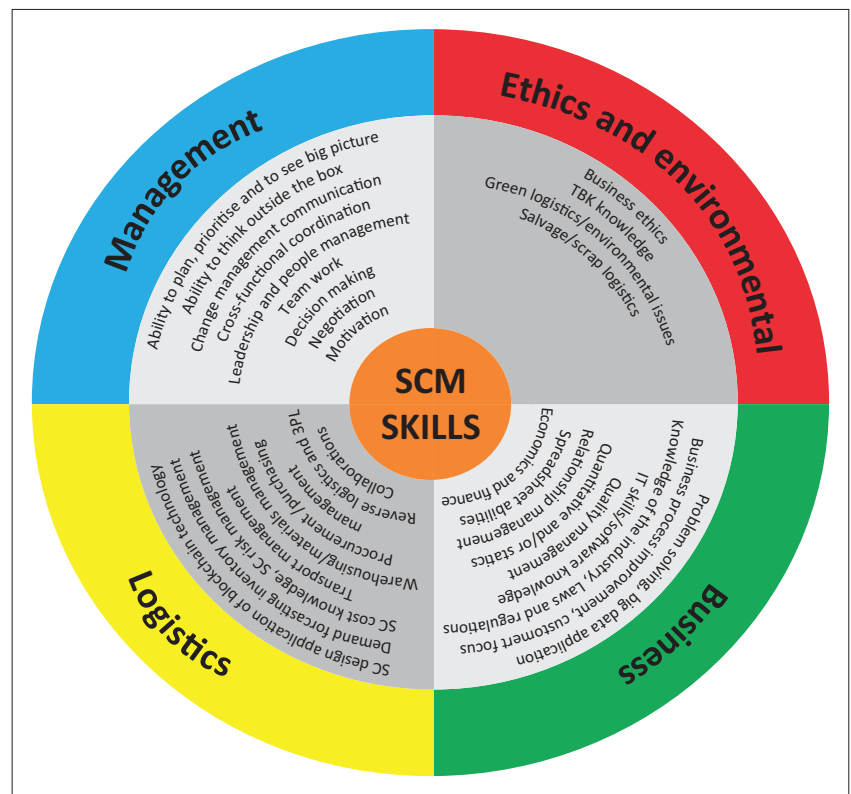

SCM, supply chain management; IT, information technology; SC, supply chain; TBL, triple bottom line.

FIGURE 8: Proposed supply chain management skills framework. 
(Jordan \& Bak 2016). Consequently, SCM researchers have held that SC managers should have skills on the information systems required to create the required transformations in SC processes (Heyns \& Luke 2012; Kotzab et al. 2018; Thai et al. 2011). In addition, the managers should have some knowledge on the potential benefits of big data and artificial intelligence to SCM (Akbari 2018).

Skills related to quality management such as total quality management and lean management offer opportunities to transform business operations to meet the needs of customers. As such, quality management has been identified as an important skill that SC managers should possess now and in the future (Bölsche et al. 2013; Heyns \& Luke 2012; Rahman \& Qing 2014). In addition, SC managers should have an understanding of logistics relevant to the business industry where they operate so that they can provide the expected improvements in the business processes (Kotzab et al. 2018). Therefore, although there are more than a dozen skills related to the business group, the few discussed here were gleaned from extant literature and considered as critical to SC managers' duties. A full list of the business group skills is illustrated in Figure 8.

\section{Logistics skills group}

Extant literature shows that SCs are expanding globally. However, different regions have varied developments in logistics in terms of infrastructure and business regulations thus offering challenges as goods transit from one region to another. The challenges create complex SC operations that call for SC professionals to be equipped with special skills to help meet customer requirements at minimum cost. As such, Cronjé (2015) argued that SC professionals in developing countries should possess more of the core logistics skills and less management skills to manage the SC complexities. Some of the key logistics skills identified include inventory management, demand forecasting, customer service, transportation management, supplier and customer relationship management and logistics planning (Cronjé 2015; Murphy \& Poist 1991; Thai \& Yeo 2015). Similarly, Heyns and Luke (2012) identified skills related to total logistics costs as among the most important in South Africa. Jordan and Bak (2016) argued that future SCM professionals should have knowledge of regulations and continuous training on logistics areas. Similarly, Kotzab et al. (2018) observed that SC managers should be ready to learn continuously to acquire new knowledge and design more effective and efficient processes as SCM leverages on technology advancements.

Researchers agree also that SC managers should possess skills related to relationship management which might include inter-organisational process coordination and nontraditional skills like logistics outsourcing and end-to-end SC thinking which are likely to help them effectively coordinate upstream and downstream processes (Lorentz et al. 2013; Remko \& Wagner 2013; Trautrims et al. 2016). In addition, SC design, procurement management, facility location, reverse logistics and SC risk management were identified as important hard skills that SC managers should possess under the logistics group (Akbari 2018; Dubey \& Gunasekaran 2015; Rahman \& Qing 2014; Sinha et al. 2016; Wu 2006) as illustrated in Figure 8.

Under the logistics group, reverse logistics was considered a fundamental SC skill that will be in high demand especially with increased e-commerce across the globe, as well as a heightened awareness of sustainability in SCs (Rajakaruna et al. 2017; Tatham et al. 2017). Finally, with the continued need for SC transparency and sustained record keeping the emergence of blockchain technologies are likely to equip SC managers of the future with skills and knowledge that will create high SC visibility (Langley \& Infosys 2019). The managers need not be equipped with the technical skills but should understand the applications and capabilities of the blockchain technologies, to help design SCs that leverage the best technologies.

\section{Ethics and environmental}

Climate change has led to an increased campaign on environmental awareness and knowledge regarding the triple bottom line in SCM, requiring SC managers to promote environmentally friendly SC practices (Dubey \& Gunasekaran 2015). As such, future logistics professionals should possess skills related to SC sustainability such as green logistics (Cvetić et al. 2017; Onar et al. 2013). Salvage or scrap disposal is among the few skills that were indicated as the least important among SC managers, although it has been consistently recognised by researchers (Cvetić et al. 2017; Murphy \& Poist 1991; Thai 2012). However, with increased awareness on sustainability, SCs are more concerned with their waste now than they were before. The main concern is how it should be disposed of and thus it requires managers to be equipped with the relevant skills such as reverse logistics of scrap or waste (Dubey \& Gunasekaran 2015). In this framework (see Figure 8), skills related to business ethics were also identified as important for SC managers. These may include the ethical conduct of business transactions and knowing how to identify unethical business behaviour along the SC.

\section{Conclusion and further studies}

The objectives of this study were to provide a list of SC skills presented in the literature, to identify SCM skills frameworks in the literature and to propose an SCM skills grouping framework. There are many skills that have been presented in the literature in addition to the first 83 skills by Murphy and Poist (1991). A total of 270 SC skills were counted, and a list was provided in Appendix 1 (Figure 1-A1). It is apparent that SC researchers do not have standardised name(s) for the skills identified over time, thus making it difficult to compare skills from one study to another or even from country to country. For example, same skills have been called different 
names in different studies; for example, manage teams, effective team leadership and leadership skills (Ellinger \& Ellinger 2014); people skills, people management and human resource management (Murphy \& Poist 1991; Rahman \& Qing 2014); as well as purchasing and procurement (Murphy \& Poist 1991). Noteworthy is also the importance researchers have placed on skills related to logistics, teamwork, communication, relationship management, international trade, continuous learning and critical thinking. The emergence of skills like the application of blockchain technology and sustainable SCM has also been observed in literature (Langley \& Infosys 2019). Therefore, there is a strong need that SC researchers should develop a common language on SCM skills so as to properly guide practitioners. It is also noted that the list of SC skills used in subsequent studies after Murphy and Poist's (1991) study has been decreasing, whereby some skills have been combined, while others have become obsolete and thus eliminated (Thai 2012). Finally, it is observed that new skills are emerging as technology advances, customer requirements change as SC integration becomes an industry practice.

Extant research on SC frameworks is fragmented without any clear standard on how SC skills can be grouped, and which framework is fit for a specific industry. As such, authors have investigated SC skills using different frameworks. This study has been successful in taking stock of the existing SCM skills frameworks; the identified frameworks include the BLM by Murphy and Poist (1991), which was validated by Razzaque and Sirat (2001), Thai (2012), Wu et al. (2013) and Thai and Yeo (2015). The T-shaped skills framework was advanced by Mangan and Christopher (2005) and later supported by Bölsche et al. (2013) and Tatham et al. (2017). The expert level skills framework was advanced by $\mathrm{Wu}$ (2006), the competence-performance framework was developed by Lorentz et al. (2013) and the SCM skills framework was established by Rahman and Qing (2014) and Sinha et al. (2016). Another framework that has received some attention in the literature is the hard and soft skills by Abreu and Alcântara (2015), Dubey and Gunasekaran (2015) and Trautrims et al. (2016). In addition, Cronjé (2015) and Cvetić et al. (2017) argued that SCM skills can be classified as functional or core and general management. The varied number of frameworks established with different numbers of skills does not guide practitioners or the industry as expected. Therefore, this study is an attempt to propose an SCM skills grouping framework based on the existing literature.

The proposed grouping framework classified SCM skills into (1) business, (2) logistics, (3) management and (4) ethics and environmental. This implies that the BLM framework by Murphy and Poist (1991) is held with an addition of ethics and environmental. However, the skill sets per group have been revised in line with the contemporary SCM skills literature. The skills have been reduced in number to 13, 11, 12 and 3 for the business, logistics, management and ethics and environmental, respectively, as illustrated in Figure 8. We argue that the skills' list per group can be contingencybased, in line with industry and organisational requirements.
The framework is likely to help managers be aware of which skills groups they should focus on. The skills list per group can be selected on a contingent basis, but should be in line with organisational and specific industry needs. The proposed framework is likely to reduce the fragmentation of SC skills groupings and sets a base for future research in this area. The new framework is unique as it has combined knowledge from the existing frameworks. It is also highly flexible, as the skills lists can be contingency based on industry or SC requirements. The framework also helps advance SCM skills research by contributing to the SCM body of knowledge.

The research is limited to the previous studies reviewed and, as such, the proposed framework may need to be tested empirically among SC managers in manufacturing and service industries. A comparative study between countries or regions may offer more insights compared to a single industry study. Another potential future research direction would be to compare the skills needed by SC managers in manufacturing and service organisations. Future research should also assess the relative importance of SC skills in various business contexts.

\section{Acknowledgements Competing interests}

The authors have declared that no competing interests exist.

\section{Authors' contributions}

J.M. and R.L. conceptualised the article. J.M. designed and developed the article including the literature review, data collection, discussion and conclusion. R.L. critically reviewed the article and authorised it for publication.

\section{Funding information}

This research was not funded by any funding agency.

\section{Data availability statement:}

Data sharing is not applicable to this article as no new data were created or analysed in this study.

\section{Disclaimer}

The views and opinions expressed in this article are those of the authors and do not necessarily reflect the official policy or position of any affiliated agency of the authors.

\section{References}

Abreu, A. \& Alcântara, R.L.C., 2015, 'Supply chain managers: Professional profile and the role in the cross-functional integration of supply chain management', Independent Journal of Management \& Production 6(1), viewed 15 March 2018, from http://www.ijmp.jor.br/index.php/ijmp/article/view/246.

Akbari, M., 2018, 'Logistics outsourcing: A structured literature review', Benchmarking: An International Journal 25(5), 1548-1580.

Bastas, A. \& Liyanage, K., 2018, 'Sustainable supply chain quality management: A systematic review', Journal of Cleaner Production 181, 726-744. https://doi. org/10.1016/j.jclepro.2018.01.110 
Bölsche, D., Klumpp, M. \& Abidi, H., 2013, 'Specific competencies in humanitarian logistics education' Journal of Humanitarian Logistics and Supply Chain Management 3(2), 99-128. https://doi.org/10.1108/JHLSCM-08-2012-0019

Cronjé, J.N., 2015, 'Logistics management skills development: A Zimbabwean case', Journal of Transport and Supply Chain Management 9(1). https://doi. org/10.4102/jtscm.v9i1.161

Cvetić, B., Vasiljević, D. \& Danilović, M., 2017, 'Competence requirements for logistics managers in the Republic of Serbia', Management: Journal of Sustainable Business and Management Solutions in Emerging Economies 22(2) 37, viewed 15 March 2018, from http://management.fon.bg.ac.rs/index.php/ $\mathrm{mng} / \mathrm{article} / \mathrm{view} / 87$.

Dubey, R. \& Gunasekaran, A., 2015, 'Shortage of sustainable supply chain talent: An industrial training framework', Industrial and Commercial Training 47(2), 86-94. https://doi.org/10.1108/ICT-08-2014-0052

Ellinger, A.E. \& Ellinger, A.D., 2014, 'Leveraging human resource development expertise to improve supply chain managers' skills and competencies', European Journal of Training and Development 38(1/2), 118-135. https://doi.org/10.1108/ EJTD-09-2013-0093

Heyns, G. \& Luke, R., 2012, 'Skills requirements in the supply chain industry in South Africa', Journal of Transport and Supply Chain Management 6(1), 107-125. https://doi.org/10.4102/jtscm.v6i1.34

Jordan, C. \& Bak, O., 2016, 'The growing scale and scope of the supply chain A reflection on supply chain graduate skills', Supply Chain Management: An International Journal 21(5), 610-626. https://doi.org/10.1108/SCM-02-20160059

Keller, S.B. \& Ozment, J., 2009, 'Research on personnel issues published in leading logistics journals', The International Journal of Logistics Management 20(3), 378-407. https://doi.org/10.1108/09574090911002832

Kotzab, H., Teller, C., Bourlakis, M. \& Wünsche, S., 2018, 'Key competences of logistics and SCM professionals - The lifelong learning perspective', Supply Chain Management: An International Journal 23(1), 50-64. https://doi.org/10.1108/ SCM-02-2017-0079

Langley, C.J. \& Infosys, 2019, 2019 Third-party logistics (3PL) study - The state of logistics outsourcing: Result and findings of the $23^{\text {rd }}$ annual study, Infosys Consulting, viewed 16 March 2019, from http://www.3plstudy. com/3pl2017download.php.

Lima-Junior, F.R. \& Carpinetti, L.C.R., 2017, 'Quantitative models for supply chain performance evaluation: A literature review', Computers and Industrial Engineering 113(September), 333-346. https://doi.org/10.1016/j.cie.2017.09.022

Lorentz, H., Töyli, J., Solakivi, T. \& Ojala, L., 2013, 'Priorities and determinants for supply chain management skills development in manufacturing firms', Supply Chain Management: An International Journal 18(4), 358-375. https://doi. org/10.1108/SCM-03-2012-0111

Mangan, J. \& Christopher, M., 2005, 'Management development and the supply chain manager of the future', The International Journal of Logistics Management 16(2) 178-191. https://doi.org/10.1108/09574090510634494

Murphy, P.R. \& Poist, R.F., 1991, 'Skill requirements of senior-level logisticians: Practitioner perspectives', International Journal of Physical Distribution \& Logistics Management 21(3), 3-14. https://doi.org/10.1108/09600039110004025

Murphy, P.R. \& Poist, R.F., 2006, 'Skill of contemporary requirements and entry-level logistics managers: A comparative analysis', Transportation Journal 45(3), 46-60.

Murphy, P.R. \& Poist, R.F., 2007, 'Skill requirements of senior-level logisticians: A longitudinal assessment', Supply Chain Management: An International Journa 12(6), 423-431. https://doi.org/10.1108/13598540710826353
Onar, S., Aktas, E., Topcu, Y. \& Doran, D., 2013, 'An analysis of supply chain related graduate programmes in Europe', Supply Chain Management: An International graduate programmes in Europe', Supply Chain Management: An Inte

Poist, R.F., Scheraga, C.A. \& Semeijn, J., 2001, 'Preparation of logistics managers for the contemporary environment of the European Union', International Journal of Physical Distribution \& Logistics Management 31(7), 487-505.

Rahman, S. \& Qing, N., 2014, 'Graduate students' perceptions of supply chain skills for supply chain managers', Benchmarking: An International Journal 21(2) 276-299. https://doi.org/10.1108/BIJ-01-2012-0002

Rajakaruna, S., Wijeratne, W.A., Mann, S.T. \& Yan, C., 2017, 'Identifying key skill sets in humanitarian logistics: Developing a model for Sri Lanka', International Journal of Disaster Risk Reduction 24 (November 2016), 58-65. https://doi.org/10.1016/j. ijdrr.2017.05.009

Razzaque, M.A. \& Sirat, M.S., 2001, 'Skill requirements: Perception of the senior Asian logisticians', International Journal of Physical Distribution \& Logistics Management 31(5), 374-395. http://doi.org/10.1108/09600030110395175

Remko, H. \& Wagner, B., 2013, 'Supply chain management (SCM): current education provision and practitioner future needs', Supply Chain Management: A International Journal 18(4). https://doi.org/10.1108/scm.2013.17718daa.001

Sinha, A., Millhiser, W.P. \& He, Y., 2016, 'Matching supply with demand in supply chain management education', The International Journal of Logistics Management 27(3), 837-861. https://doi.org/10.1108/IJLM-03-2015-0058

Tatham, P., Wu, Y., Kovács, G. \& Butcher, T., 2017, 'Supply chain management skills to sense and seize opportunities', The International Journal of Logistics Management 28(2), 266-289. https://doi.org/10.1108/IJLM-04-2014-0066

Thai, V.V., 2012, 'Competency requirements for professionals in logistics and supply chain management', International Journal of Logistics Research and Applications 15(2), 109-126.

Thai, V.V., Cahoon, S. \& Tran, H.T., 2011, 'Skill requirements for logistics professionals: Findings and implications', Asia Pacific Journal of Marketing and Logistics 23(4) pp. 553-574. https://doi.org/10.1108/13555851111165084

Thai, V.V. \& Yeo, G.-T., 2015, 'Perceived competencies required for container shipping logisticians in Singapore and South Korea', The International Journal of Logistics Management 26(2), 334-355. https://doi.org/10.1108/IJLM-02-2014-0031

Thomas, J. \& Harden, A., 2008, 'Methods for the thematic synthesis of qualitative research in systematic reviews', BMC Medical Research Methodology 8(1), 45. https://doi.org/10.1186/1471-2288-8-45

Tian, M., Deng, P., Zhang, Y. \& Salmador, M.P., 2018, 'How does culture influence innovation? A systematic literature review', Management Decision 56(5), 1088-1107.

Trautrims, A., Defee, C. \& Farris, T., 2016, 'Preparing business students for workplace reality - Using global virtual teams in logistics and SCM education' The International Journal of Logistics Management 27(3), 886-907. https://doi. org/10.1108/IJLM-01-2015-0003

Wong, Y.C., Grant, B.D., Allan, B. \& Jasiuvian, I., 2014, 'Logistics and supply chain education and jobs: A study of UK markets', The International Journal of Logistics Management 25(3), 537-552. https://doi.org/10.1108/IJLM-01-2013-0003

Wu, Y., 2006, 'Skill requirements for logistics license in Taiwan', Supply Chain Management: An International Journal 11(5), 415-424. https://doi. org/10.1108/13598540610682435

Wu, Y., Huang, S., Goh, M. \& Hsieh, Y., 2013, 'Global logistics management curriculum Perspective from practitioners in Taiwan', Supply Chain Management: An International Journal 18(4), 376-388. https://doi.org/10.1108/SCM-04-20120145 


\section{Appendix 1}

FIGURE 1-A1: Supply chain management skills.

\begin{tabular}{|c|c|c|}
\hline Skills & Skills & Skills \\
\hline Ability to adapt to organisational change & Adeptness at managing ambiguity & Business process improvement \\
\hline Ability to delegate responsibility & Adventurous & Business regulations \\
\hline Ability to display statesmanship & Aggregate planning in supply chain/S\&OP & Business software \\
\hline Ability to innovate & Analytical problem-oriented work & Business writing \\
\hline Ability to listen & Analytical reasoning ability & Capacity planning \\
\hline Ability to manage diversity & Appearance & Cargo handling operations \\
\hline Ability to manage time & Assertiveness & Change management and influencing skills \\
\hline Ability to motivate staff & Assign tasks effectively & Channel concept \\
\hline Ability to negotiate & Attention to details & Charisma \\
\hline Ability to organise & Awareness of the needs of other & Choreographer \\
\hline Ability to persuade & Basic cost accounting & Critical thinking \\
\hline Ability to plan and prioritise & Basic E-commerce knowledge & Collaboration, alliances, process improvement \\
\hline Ability to see the 'big picture' & Material handling equipment skills & Communication skills - written \& oral \\
\hline Ability to supervise & Being a good corporate citizen & Complex problem-solving skills \\
\hline Ability to train subordinates & Boundary spanning management & Containership \\
\hline Ability to view firm as a system & Business and government & Continuous learning \\
\hline Accounting and cost control & Business and society & Contract management \\
\hline Adaptability or flexibility & Business ethics & Facility location/Network design \\
\hline Controlling & Business law & Financial management \\
\hline Coordinate the work - and lifetimes & Designing supply chain & Fleet size and mix decisions \\
\hline Corporate social responsibility & Developing environmentally sustainable logistics systems & Flexibility \\
\hline Cost analysis & Distribution communications & Flexibility and adaptability \\
\hline Cost reduction & Distribution management & Focus on processes/flows \\
\hline Creativity & Distribution planning & Freight forwarding and shipping skills \\
\hline Critical thinking & Documentation proficiency & Global orientation \\
\hline Cross-functional management & Drive for results & Good guanxi networks \\
\hline Cross-functional skills & E-business/E-commerce & Good sense of humour \\
\hline Customer and distribution channel management & Economic geography & Goods loading/unloading ability \\
\hline Customs import and export & Engineering logistics & Higher order problem-solving \\
\hline Dangerous cargo regulations & Enthusiasm & Honesty and integrity \\
\hline Data management & ERP systems & Human resource management \\
\hline Data mining & Expertise in foreign language & Identify environmental opportunities/threats \\
\hline Dealing with ambiguity & Expertise in interpersonal relations & Identifying opportunities and threats \\
\hline Decision-making & INCOTERMS knowledge & Independence and own initiative \\
\hline Demand forecasting and supply planning & Exposure to TBL framework & Individual time management \\
\hline Demand forecasting/demand management & Extroversion and conscientiousness & Industrial engineering \\
\hline Information systems & Facilities location & Industrial management and statistics \\
\hline Information technology skill & Logistics in emerging markets & Industrial relations \\
\hline Infrastructure planning and management & Logistics industry analysis & Industrial sociology \\
\hline Insurance & Logistics information systems & Information and communication technologies \\
\hline Integration of system and process & Logistics management skills & Information gathering \\
\hline Integrative decision-making & Logistics performance analysis & Information integration \\
\hline International business regulations & Maintenance management & Information sharing \\
\hline International logistics and global issues & Management of complexity and change & Information system for logistics and production control \\
\hline International regulatory changes & Managing corporate knowledge & Information system management \\
\hline International transportation & Managing organisational culture & Operations research \\
\hline Inventory management/control & Manufacturing management & Operations strategy \\
\hline ISO 14000 Standards & Maritime economics & Order processing \\
\hline JIT/Lean & Maritime law and marine insurance & Organisational psychology \\
\hline Knowledge of operations & Market analysis & Organisational skills \\
\hline Knowledge of the industry & Market sensitivity & Organisational leadership \\
\hline Knowledge of the infrastructure differences & Materials handling or management & Outgoing personality \\
\hline Knowledge of the latest technology & Merchandise display & Outsourcing \\
\hline Knowledge on business administration & Metrics and performance & Outsourcing/globalisation \\
\hline Labour relations & Microeconomics & Packaging \\
\hline Language skills & Modelling of operations systems & Pallet management \\
\hline
\end{tabular}


FIGURE 1-A1 (Continues...): Supply chain management skills.

\begin{tabular}{|c|c|c|}
\hline Skills & Skills & Skills \\
\hline Leadership skills & Motivation and enthusiasm & Partnership management \\
\hline Lean management & MRO and after sales support & Parts supports \\
\hline Learning ability & Multi-dimensional capabilities & Patent analysis \\
\hline Legal knowledge and skills & Multimodal transport & Traffic/transport management \\
\hline Listening & National and international mobility & Plant layout \\
\hline Location optimisation & Navigation and traffic control & Master planning \\
\hline Logical thinking & Negotiating skill & Port/airport management \\
\hline Logistic information systems & Negotiation/dispute resolution & Positive attitude \\
\hline Logistics facility planning & Negotiations capacity & Preparation of cost estimates and quotations \\
\hline Public relations & Networking skill & Presentation skills \\
\hline Quality management & Operational skills & Problem identification and solving \\
\hline Quantitative and/or statistical skills & Operations management & Process analysis/reengineering \\
\hline Quantitative modelling skill & Resource integration & Procurement/Purchasing management \\
\hline Quantitative/technical/information system & Revenue management & Product integration \\
\hline Recruiting logistics personnel & Reverse logistics skills & Product/service design \\
\hline Technical and analytics savvy & Roles and functions of ports & Production planning or scheduling or management \\
\hline Research and development & Salvage and scrap disposal & Project management \\
\hline Self-confidence & Scheduling & Understanding logistics terminology \\
\hline Self-motivation & Storage and warehousing & Understanding of green packaging \\
\hline Ship brokering and chartering & Strategic management & Urban and regional planning \\
\hline Ship routing and scheduling & Strategic planning and management & Use of logistics specialised software \\
\hline Shipping and port marketing & Stress management & Vehicle routing \\
\hline Shipping management & Supplier relationship management & World trade and shipping \\
\hline Software knowledge & Sustainability/ethics/social responsibility & Supply chain cost knowledge \\
\hline Solution-oriented & System analysis & Supply chain design \\
\hline Sourcing and supplier management & Tax laws & Supply chain management \\
\hline Spare parts support & Transportation regulation & Supply chain uncertainty/risk management \\
\hline Specialised cargo operations & Treating people with warmth & Understanding financial reports \\
\hline
\end{tabular}

TBL, triple bottom line; INCOTERMS, international commercial terms; ERP, enterprise resource planning; MRO, maintenance repair and operations; S\&OP, standard operating procedures; SCM, supply chain management. 